\title{
Estudo populacional dos mosquitos (Diptera; \\ Culicidae) em área de abrangência da Barragem de Biritiba-Mirim, SP, Brasil
}

\author{
Marcelo Sciarretta Sebastião
}

"Dissertação apresentada ao Programa de Pós - Graduação em Saúde Pública para a obtenção do título de Mestre em Saúde Pública".

Área de concentração: Epidemiologia Orientadora Prof ${ }^{a}$ Dr $^{a}$ : Iná Kakitani

São Paulo

2005

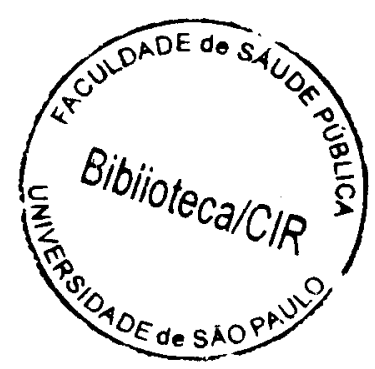




$$
45799 / 2005 \text { doc }
$$

Autorizo, exclusivamente para fins acadêmicos e científicos, a
reprodução total ou parcial desta tese, por processos fotocopiadores.
Assinatura:
Data:




\section{AGRADECIMENTOS}

Aos meus pais João Sebastião e Giulia Sciarretta Sebastião, minhas irmãs Andréa, Vanessa e para minha namorada Ismalia meu amor, por toda confiança, incentivos e carinho oferecidos em todos os momentos.

À Professora Dr Iná Kakitani pela orientação, sugestões e incansável dedicação.

Aos Professores Dr ${ }^{\mathrm{es}}$ Délsio Natal, Maria Anice Mureb Sallum, Eunice Aparecida Bianchi Galati e José Maria Soares Barata pelos ensinamentos oferecidos ao longo deste trabalho.

Aos Biólogos Márcia Bicudo de Paula, Marcia Gutierrez de Castro e Aristides Fernandes pelo apoio nas atividades laboratoriais

Aos Biólogos Luís Fellipe Mucci, Juliana Telles de Deus, Marcos Takashi Obara, Walter Ceretti Junior, Paulo R. Urbinatti Helene M. Ueno e Mauro B. Fonseca pela amizade e paciência.

Ao Técnico em Processamento de Dados Rodrigo Alexandre Sportello e meu amigo Márcio Bonoli pelo suporte operacional.

Ao Departamento de Epidemiologia da Faculdade de Saúde Pública/USP, pelo apoio logístico e institucional.

A equipe da RV Consultoria, Sebastião Carlos dos Santos, Patrícia Beloto Bertola, José Roberto Dias, José Donizete Soares, Sebastião Antônio dos Santos, pelo apoio nas atividades de campo. 
À Edna Pinto Pereira de Sousa Do Instituto Nacional de Meteorologia (INMET) por fornecer os dados de temperatura, ao Departamento de Água e Energia Elétrica (DAEE) pelo fornecimento dos dados pluviométricos.

Ao CNPq por concessão de bolsa de estudo durante doze meses e ao Professor Dr. Almério de Castro Gomes, pelo apoio logístico, na qualidade de Coordenador do Projeto de Epidemiologia das Barragens de Biritiba-Mirim e Paraitinga. 


\section{ÍNDICE}

1. INTRODUÇÃO 01

$\begin{array}{ll}1.1 \text { Hidrografia e saúde pública } & 06\end{array}$

$\begin{array}{ll}\text { 2. OBJETIVOS } & 07\end{array}$

$\begin{array}{ll}2.1 \text { Objetivo Geral } & 07\end{array}$

$\begin{array}{ll}2.2 \text { Objetivos Específicos } & 07\end{array}$

3. MATERIAL E MÉTODOS 08

$\begin{array}{ll}3.1 \text { Área de estudo } & 08\end{array}$

$\begin{array}{ll}3.2 \text { Composição vegetal } & 10\end{array}$

3.3 Técnicas de coleta 11

$\begin{array}{ll}3.4 \text { Croqui } & 12\end{array}$

$\begin{array}{ll}3.5 \text { Período de coleta } & 12\end{array}$

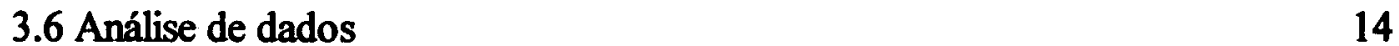

$\begin{array}{lr}\text { 4. RESULTADOS } & 18\end{array}$

$\begin{array}{ll}\text { 5. DISCUSSÃO } & 28\end{array}$

6. CONCLUSÕES

$\begin{array}{ll}\text { 7. REFERÊNCIAS } & 39\end{array}$

$\begin{array}{ll}\text { ANEXOS } & 46\end{array}$ 


\section{RESUMO}

Sebastião MS. Estudo da diversidade de mosquito (Diptera; Culicidae) em área de abrangência da Barragem de Biritiba-Mirim, SP, Brasil. São Paulo; 2004. [Dissertação de Mestrado - Faculdade de Saúde Pública da USP].

Objetivo. Conhecer a fauna culicideana no período de pré-enchimento da Barragem de Biritiba-Mirim, Estado de São Paulo, Brasil. Métodos As coletas de Culicídeos adultos e imaturos foram de caráter semanal no período de 12 (doze) meses (fase anterior ao enchimento). Os adultos foram coletados com armadilha $\mathrm{CDC}+$ gelo seco em dois sítios de coleta, entre os horários de crepúsculo vespertino e matutino (das $17 \mathrm{~h}$ às $09 \mathrm{~h}$ totalizando 16 horas de coleta) e armadilha de Shannon, também em dois sítios de coleta, (no período das $17 \mathrm{~h}$ às $20 \mathrm{~h}$ ) totalizando 03horas de coleta abrangendo o crepúsculo vespertino. A coleta de imaturos foi realizada com conchas de $500 \mathrm{ml}$ e pipeta. As variáveis ambientais como; pluviosidade, temperatura, regime dos ventos, foram levadas em conta na interferência faunística deste estudo. Resultados foram coletados 8.139 mosquitos distribuídos em 71 espécies (ou grupo de culicídeos). Os gêneros mais destacados foram Mansonia, Coquillettidea, Anopheles, Culex, Aedeomyia,. Mansonia titillans, Adeomyia squamipennis, Anopheles galvaoi, foram as espécies mais abundantes. Conclusão A construção de empreendimentos hídricos pode propiciar grande proliferação de vetores, intensificando a transmissão de algumas doenças, bem como a introdução de outras. Assim, pesquisas necessitam ser desenvolvidas e, com base nelas medidas de prevenção e controle.

Descritores: Culicidae, Barragem, diversidade. 


\section{ABSTRACT}

Sebastião MS. Estudy of diversity of mosquito (Diptera: Culicidae) in area under influence of Biritiba-Mirim dam SP, Brazil. São Paulo; 2004. [M. Sc. Dissertation - Faculdade de Saúde Pública da Universidade de São Paulo, Brazil].

Objective- know the mosquitos fauna before the formation of the lake of BiritibaMirim dam, Sao Paulo, state Brazil. Methods- Adults and immatures were collectec every week in a period of 12 months. Shannon and CDC traps were used in collect of adults in 2 areas but three and sixteen hours each. The immatures were collected with $500 \mathrm{ml}$ scoops.

The interference of temperature, rain and wind variability of the specific fauna composition of the habitats were observed. Results 8.139 mosquitos were collected in 71 species or groups. The genera in which density of adult specimems reached the highest values were Mansonia Coquillettidea Anophles Culex Aedeomyia.

Conclusion The constructionof a dam can propitiate the procriation of vectors and increasing the transmission of some diseases. Thus demanding preventive programs to be develop with the support of faunistic studies.

Descriptors- Culicidae, Dam, Diversity. 
"Nada hay mas estimulante em las ciencias de la salud que la Epidemiología. Es uma disciplina donde se encuentram los tres aspectos fundamentales en la medicina: El aspecto científico, el aspecto social y el aspecto humano." (LECHAT 1977). 


\section{INTRODUÇÃO}

$\mathrm{Na}$ Epidemiologia, o problema tem origem quando doenças (ou agravos à saúde, de qualquer natureza) acometem grupos humanos. É a necessidade de remover fatores ambientais, sociais, biológicos ou físico-químicos contrários à saúde, implicando a criação de condições que a promovam, que determina a problemática própria da Epidemiologia (ROUQUAYROL e ALMEIDA-FILHO 1999).

Historicamente as práticas culturais são formadas quando o homem atua em relação às adversidades e soluciona seus conflitos. Os hábitos e comportamentos que se transformam ao longo do tempo, em fatores culturais expressam freqüentemente comportamentos relativos às necessidades individuais $\mathrm{e}$ familiares frente às adversidades e facilidades do meio, refletindo-se na esfera social da comunidade (MÜLLER 1995).

Na sociedade moderna, o homem tem conseguido os produtos essenciais à sua sobrevivência e os bens que consome, interferindo drasticamente nos ecossistemas de que se serve, transformando-os de forma profunda e, com frequiência, desencadeando graves reflexos sobre a vida no planeta. Săo transformaçð̃es impostas por um modelo em que os processos produtivos, tidos como economicamente viáveis, levam à substituição dos sistemas naturais por formas artificiais de se conseguirem os bens e produtos que a sociedade requer.

Esse modelo não só tem provocado desequilibrio e empobrecimento do meio físico, não raro irreversíveis, e conseqüentemente contribuído para mudanças na qualidade de vida, bem como uma crescente dependência de tecnologia e insumos, de que em muitos casos o País não dispõe (FUNDAÇÃO IBGE 2000).

A atividade humana, e sua grande capacidade competitiva fazem com que os ecossistemas assim modificados apresentem gradual empobrecimento de sua parte biótica, tanto animal como vegetal. Assim, a ocupação de novo habitat, por parte de determinada população, resulta inevitavelmente em outras modificações desse ecótopo. Este também recebe o nome ecossistema consumidor ou importador.

A mudança ambiental oriunda de processos globais e locais possui o mesmo tipo de efeito nos vetores de doenças, por exemplo um aumento da temperatura pode alterar a distribuição dos artrópodes vetores de patógenos, sua abundância e mesmo 
seu ciclo de vida pode ser abreviado. Os efeitos específicos dessas transformações ambientais são de difíceis previsões. Estudos realizados pelo "International Panel on Climate Change" 1990 prevêem que em até 2025 , ocorrerá um aumento de $2^{\circ} \mathrm{C}$ na temperatura terrestre. Esta mudança acarretará um acréscimo equivalente a $180 \mathrm{Km}$ de latitude ou $300 \mathrm{~m}$ de altitude. Ampliando a área de atuação dos artrópodes vetores (HARRINGTON e STORK 1995).

Para prognosticar as hipóteses relativas ao que ocorrerá em regióes específicas da Terra há de dispor de conhecimentos prévios sobre as características geográficas, hábitos da fauna em questão, comportamento humano que possa influir na veiculação da parasitose (FORATTINI 2002).

Um dos aspectos que vale ressaltar diz respeito a crescente expansão da população em todo mundo, a qual vem aumentando a demanda de água potável necessária ao abastecimento ocasionando graves problemas aos aglomerados humanos. Desde o princípio da História, a sociedade humana tendeu a localizar-se e a desenvolver-se ao redor dos rios, lagos e outras fontes de água. Com o passar dos tempos, entretanto, as populações aumentaram desproporcionalmente, levando às modificações no padrão, intensidade e frequêencia de uso do recurso hídrico. A produção de energia elétrica é um dos resultados altamente positivos da utilização dos recursos hídricos, a qual beneficia as necessidades energéticas do país (FUNDAÇÃO IBGE 1999).

Os impactos produzidos pelas diversas formas de obter energia, sobre a sociedade e o meio ambiente, são variáveis. Ocorrem na implantação dos aproveitamentos hidrelétricos, na exploração de jazidas energéticas, e na operação das usinas, dentre as diversas formas de extrativismo. Reconhecer esses impactos dimensioná-los e tratá-los, antes que se constituam problemas, é a preocupação das pesquisas da Saúde Pública (MÜLLER 1995).

O impacto ambiental das grandes obras construídas pelo setor elétrico no Brasil é, na atualidade, um ponto de grande debate na sociedade civil e dentro do próprio governo. Indiscutivelmente, existe a necessidade de construir as usinas e linhas de transmissão para a produção e o transporte da energia elétrica, como também não há dúvida de essas obras causam profundos impactos nos meios: físico, biótico e sócio-econômico (ROUQUAYROL e ALMEIDA-FILHO 2003). 
Nos dias de hoje questiona-se a forma como esses projetos são realizados, a partir da consideração de que é possível aproveitar os recursos hídricos e térmicos disponiveis no país e, ao mesmo tempo, tanto evitar a deterioração do meio ambiente quanto promover o desenvolvimento sócio-econômico das áreas atingidas pelas obras e, conseqüentemente, melhorar as condições de vida das populações.

Quando se constrói uma barragem, o lago formado traz perturbações no comportamento natural dos rios represados, produzindo modificações hidrológicas, geológicas, climáticas e alterando as condições físico-químicas da água. Obviamente, as repercussões na flora, na fauna e na população que habita as cercanias do lago são imediatas. Na maioria das vezes, a área alagada leva a formação de reassentamentos da população, com todas as implicações econômicas, sociais e culturais que esta tarefa tem (FILHO 1988).

No Brasil, as barragens e açudes são formados principalmente pelo represamento de rios para atender os seguintes objetivos: abastecimento de águas, regularização de cursos, obtenção de energia, irrigação, navegação e recreação entre outros.

A construção de barragens, formando lagos artificiais, produz diferentes alteraçð̃es no ambiente, ñ̃o apenas no aquático, mas também no ambiente terrestre adjacente. Estas modificaç̃̃es tanto podem ser benéficas como prejudiciais. Portanto, estudos sobre o impacto que um grande lago artificial poderá causar no ambiente são indispensáveis antes do represamento de um rio (MÜLLER 1995).

(TEODORO et al., 1995; MÜLLER 1995; HUNTER et al. 1983) destacam algumas formas de degradação ambiental decorrentes da formação do reservatório, passiveis de ocorrer. Esta degradação acarreta algumas mudanças como por exemplo; - as mudanças climáticas, especialmente a formação de nevoeiros; possível alteração nas taxas de evaporação e de evapotranspiração; modificações na circulação atmosférica, com formação de correntes locais de brisa na área do reservatório; alteração no nível do lençol freático; mudança no perfil longitudinal dos rios que desembocam no lago artificial e modificações geodinâmicas decorrentes desse fato. O problema mais grave com relação ao funcionamento de grandes barragens, é o intenso assoreamento que pode ocorrer na represa em função do acumulo de sedimentos, provenientes das bacias de contribuição regionais, que depositam ao 
chegar ao ambiente lêntico do reservatório. $O$ acumulo de matéria orgânica e de minerais eutrofizantes nas reentrâncias ou braços da represa facilita 0 desenvolvimento da vegetação marginal e reduz a profundidade de espelho d' água a uns poucos centímetros, promovendo o aquecimento da mesma e favorecendo a proliferação de mosquitos.

A fauna é função do meio que a abriga: tanto quanto nos outros organismos superiores, depende de habitat para atender suas necessidades mais elementares de alimentação, abrigo, reprodução e criação da prole. Dessas quatro, as duas primeiras necessidades estão diretamente relacionadas como meio. Qualquer intervenção sobre a quantidade (superficie) ou qualidade (diversidade) da vegetação, repercutirá diretamente na vida selvagem, afetando sua quantidade (abundância) e qualidade (diversidade) (MÜLLER 1995).

A formação de lagos artificiais leva a múltiplos impactos, tanto na fauna aquática como na flora, em decorrência da ampliação dos nichos ecológicos disponiveis. Considerando-se as represas tropicais, um aspecto que surge no contexto da formação desses grandes lagos é o crescimento exponencial de macrófitas aquáticas (Pistia e/ou Eichhornia são as mais comuns), cuja infestação em reservatórios é registrada no Brasil e em outros países (TADEI 1996).

Coleções hídricas ricas em plantas aquáticas flutuantes são propícias ao desenvolvimento de espécies de mosquitos que dependem desses vegetais para respiração ou mesmo como abrigo para suas formas imaturas. (NATAL et al. 1995)

Segundo (RACHOU 1958), esses vegetais também podem servir como dispersor de larvas de culicídeos por grandes distâncias.

A abundância desse vegetal, aliada às condições de temperatura, presença do homem e animais domésticos nas imediaçðes do lago servindo como fonte alimentar para as fềmeas dos mosquitos, garante a manutenção do ciclo completo de desenvolvimento, transformando tais empreendimentos em extensos criadouros (NATAL 1995).

A associação de mosquitos com doenças humanas como a malária, febre amarela, dengue e outras, tem estimulado investigações sobre a distribuição geográfica e de aspectos do comportamento das espécies que compõem a fauna desses culicídeos (BARBOSA et al. 1993; VAN THIEL 1962). 
A fauna de culicídeos em áreas de impacto sofre influências, tanto na sua composição, quanto na freqüência das espécies, onde alterações antrópicas da paisagem, como a construção de represas, canais de irrigação, estradas, arrozais, áreas de extração da borracha, mineração, colonização entre outras, geram situaçðes de desequilibrio e algumas espécies de mosquitos podem proliferar, acarretando problemas de incômodo ou transmissão de doenças (TADEI et al. 1983; HUNTER et al. 1983; MOUCHET et al. 1998; NATAL et al. 1995; SAWYER 1988; BAXTER 1977).

A problemática da implantação de uma barragem ocorre no período de construção, com a chegada dos trabalhadores e sua instalação, próximo às áreas naturais, o processo de ocupação, pode ocorrer até certo ponto, de forma análoga à instalação de um garimpo ou projeto de colonização, contribuindo com o desenvolvimento de criadouros. Com o impacto da atividade humana no andamento das obras, pode ocorrer a formação de novos corpos de águas estagnadas, incrementando o problema (NATAL 1995; LEE 1985).

A possível presença no canteiro de obras com trabalhadores previamente infectados com Plasmodium e a alta densidade de anofelinos, pode gerar um surto de Malária.

Com a finalização das obras e estando pronta a barragem, segue-se o período de inundação e formação do lago. Nesse período de enchimento, praticamente não há condições de proliferação de mosquitos, devido à variação contínua do nível das águas.

O periodo de estabilização que se inicia após o enchimento, dará início no lago recém formado a uma sucessão ecológica. Lagos de grande porte, uma vez preenchidos, sofrem pequenas oscilaçōes de nível, devido ao seu grande volume de água. Esse estado colabora com uma maior estabilidade das margens, propiciando um processo sucessório mais definitivo. As margens do lago serão colonizadas por gramíneas e uma variedade de macrófitas emergentes e flutuantes. Em certos pontos a proliferação de algas pode contribuir para a riqueza do plancton. Nessas condições, pode-se formar habitat propício ao desenvolvimento de larvas de culicídeos. Em contra partida lagos de pequeno porte espera-se uma oscilação maior do nível da 
água, o que pode servir de fator desfavorável ao desenvolvimento larvário nas bordas (NATAL 1995).

Em pesquisas realizadas na UHE Itaipu, verificaram-se significativas alterações nas populações de Anopheles, Aedes, Culex, Mansonia, Coquillettidia e outros, vários de interesse médico, uma vez que espécies dos gêneros citados podem transmitir enfermidades tais como a malária, febre amarela, dengue, filariose humana, encefalites entre outras doenças (MÜLLER 1995).

Outro exemplo desse fenômeno, caracterizando-se problema aconteceu na UHE Tucuruí, onde a alta densidade de mosquitos dos Mansonia (titillans e indubitans) Coquillettidia, e sua elevada antropofilia constituíram sério fator de incômodo, onde a irritação se dá pelas picadas. Os colonos abandonam suas terras gerando grandes prejuízos para agricultura e pecuária (ROSA et al. 1995; MÜLLER 1995).

\subsection{Hidrografia e saúde pública}

A hidrografia corresponde ao conjunto formado pelas águas correntes e águas estagnadas. Incluem-se aí córregos, riachos, rios, lagos, lagoas, alagadiços, barreiros, brejos e empoçamentos de águas fluviais. As valas de irrigação e drenagem, os canais e reservatórios, açudes e represas, construídos pelo homem, e, portanto, artificiais, devem ser aí incluídos por desempenhar, no ambiente, funções idênticas àquelas desempenhadas pelos componentes hidrográficos naturais.

$\mathrm{Na}$ atualidade é bastante volumoso o conhecimento que se dispze acerca do papel representado pelo coeficiente hídrico de ecótopo na difusão das doenças transmissíveis. Dentre as doenças transmitidas por mosquitos, a mais difundida é a malária. Acrescente-se a ela a febre amarela, a dengue, a filariose e a oncocercose (LEE 1985). 


\section{OBJETIVOS}

\subsection{Objetivo geral}

Estudo populacional e mensuração de características ecológicas dos mosquitos (Diptera; Culicidae) em área de abrangência da barragem de BiritibaMirim, SP Brasil.

\subsection{Objetivos específicos}

- Analisar a composição faunistica de culicídeos na região de futura inundação da barragem.

- Calcular a constância das espécies capturadas.

- Calcular a similaridade entre os dois sítios de coleta.

- Estimar a abundância de espécies utilizando duas técnicas de captura.

- Calcular a diversidade culicideana da área de estudo.

- Calcular a dominância de espécies de culicídeos na área.

- Relacionar a distribuição sazonal e espacial das espécies mais abundantes. 


\section{MÉTODOS}

\section{1 Área de estudo}

A Barragem de Biritiba-Mirim esta situada na porção leste da Região metropolitana de São Paulo, distando aproximadamente $100 \mathrm{Km}$ da Capital. O rio Biritiba-Mirim está situado entre os municípios de Mogi das Cruzes e de BiritibaMirim constituindo uma divisa natural, onde se integra no Sistema Produtor AltoTiête (SPAT).

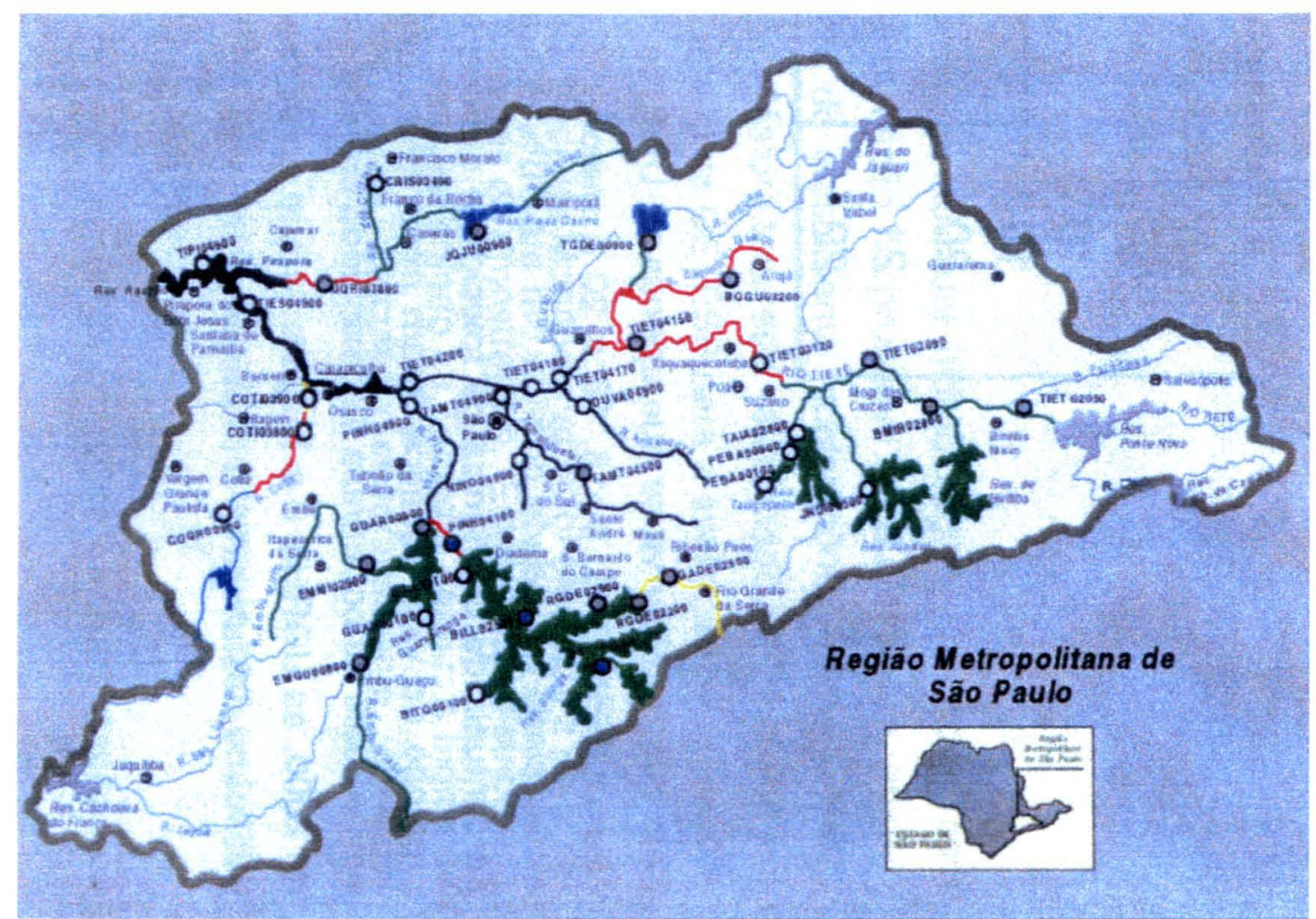

Figura 1. Mapa da região metropolitana da cidade de São Paulo (represas) (CCN 1997).

Área do reservatório: $\quad 471$ alqueires

Volume do reservatório: $34,4 \times 10^{6} \mathrm{~m}^{3}$

Altitude: $\quad 760 \mathrm{~m}$

Prazo para o enchimento:10 a 12 meses (CCN 1997) 


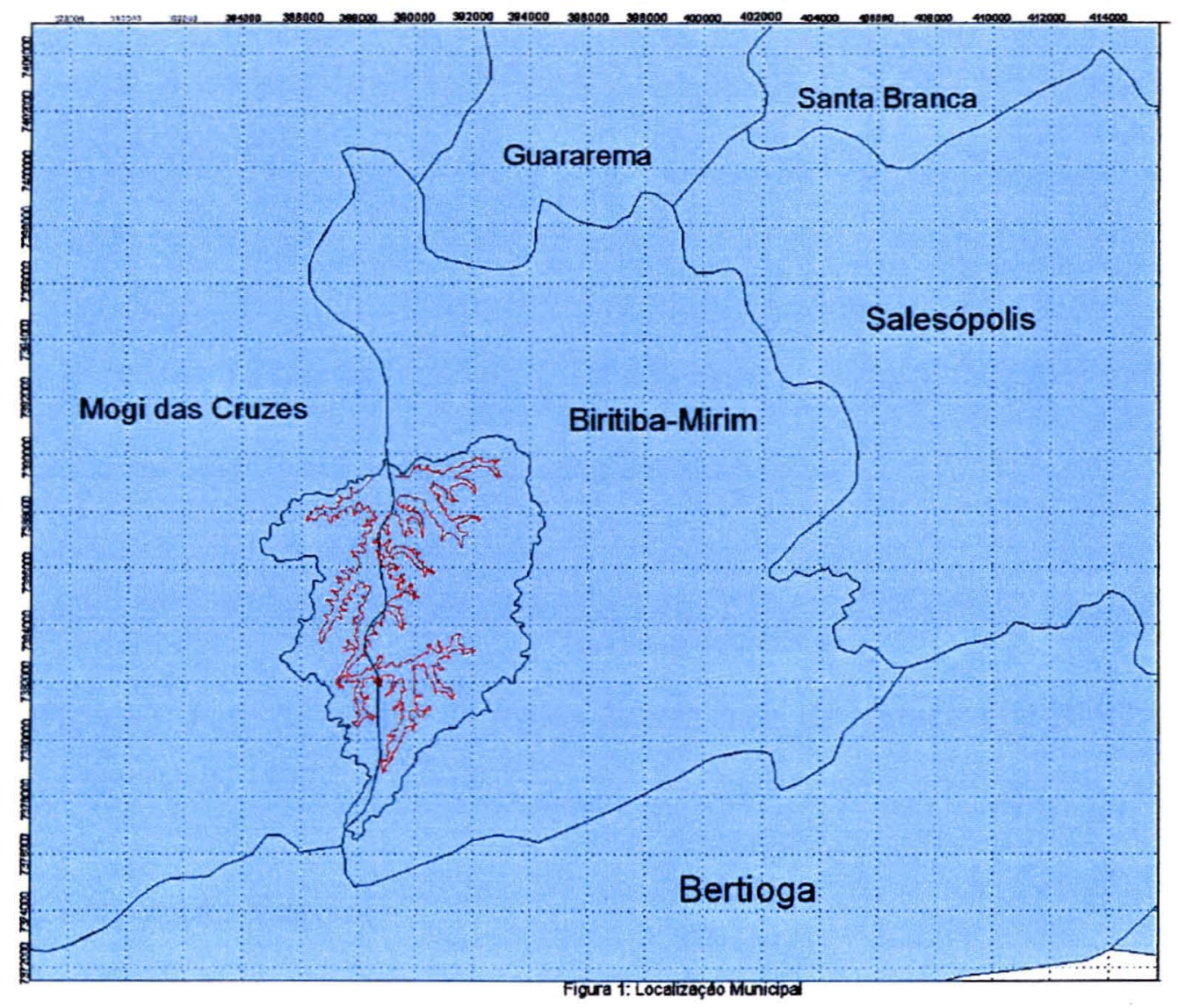

Figura 2. Limite municipal entre Mogi das Cruzes e Biritiba-Mirim (área de influência da barragem de Biritiba-Mirim). (CCN 1997) 


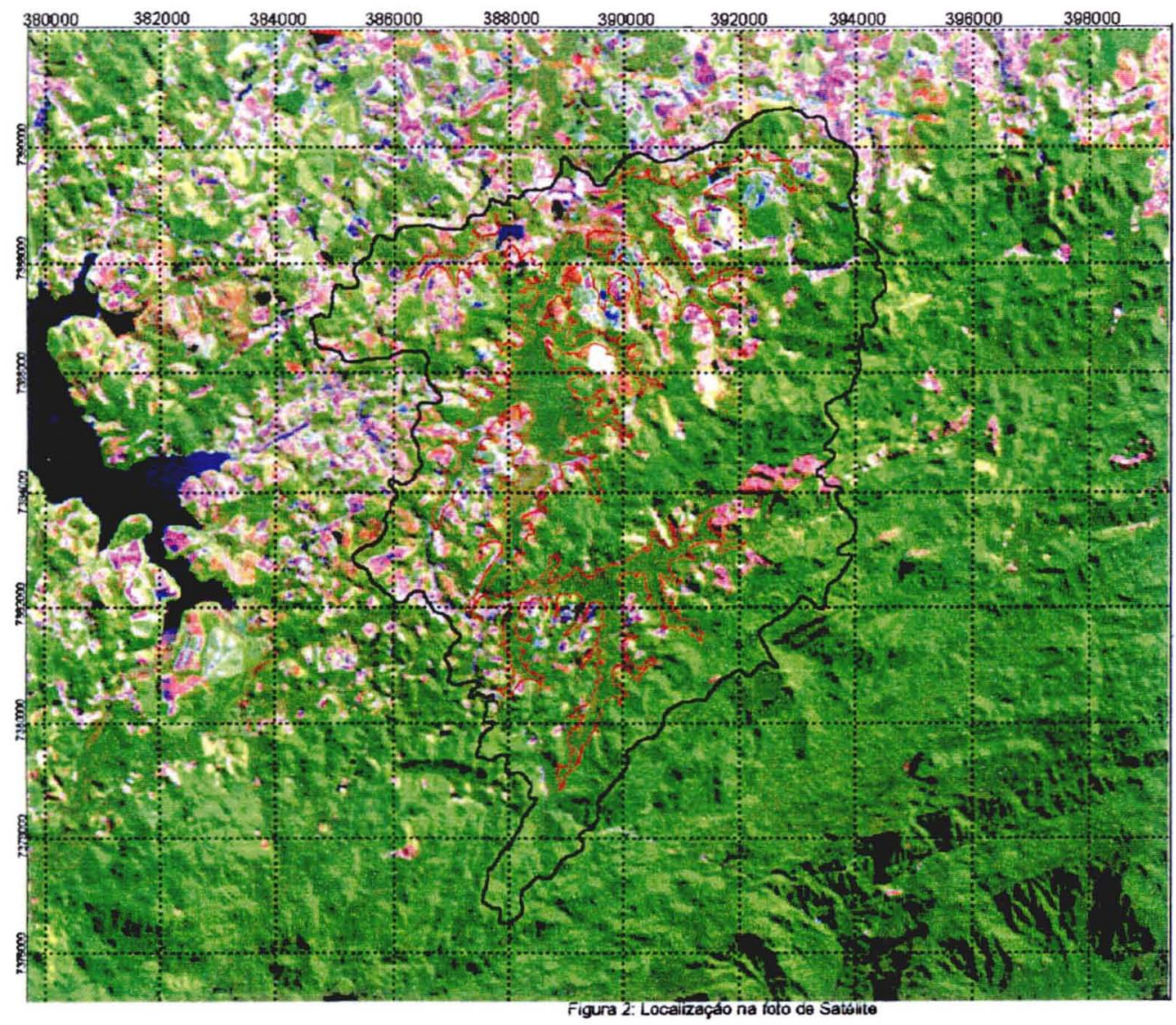

Figura 3. Foto de satélite da região de influência da barragem de BiritibaMirim. (CCN 1997)

\subsection{Composição Vegetal}

Embora a região tenha sido ocupada, primitivamente, pela Floresta Ombrófila Densa e também por Floresta Estacional Semidecidual, em boa parte de sua área, praticamente nenhuma área original representativa existe hoje. A vegetação natural remanescente se constitui de capoeira, pequena mata ciliar, matas de galeria em propriedades particulares e resíduos de cerrado. Chama a atenção na microbacia a grande área ocupada por reflorestamentos, predominantemente de eucalipto. A área de Pinus, embora tenha sido maior em outros tempos, tendendo ainda esses remanescentes serem substituídos por eucalipto, pastagens e outras atividades agrícolas. Nas áreas norte e central tem-se intensa atividade hortícola na microbacia. 
Com a formação do lago ocorrerá perda da vegetação remanescente, bem como, diversas áreas de solos cultiváveis, totalizando 159 desapropriações. (CARVALHO 2003; DAEE 2004).

\subsection{Técnicas de coleta}

Foram empregadas as Armadilhas de Shannon e CDC no levantamento da fauna de culicídeos adultos, já as formas imaturas foram coletadas utilizando-se a técnica da conchada.

Armadilha CDC (GOMES et al. 1985): visa estratificar a distribuição vertical e horizontal da composição faunística e sazonalidade dos culicídeos nas áreas investigadas (Lagoa e Morro). O horário correspondeu ao período que antecede o crepúsculo vespertino prossegue durante toda a noite e se estendendo até o crepúsculo matutino. (das $17 \mathrm{~h}$ às $9 \mathrm{~h}$ ). Totalizando 16 horas de funcionamento.

Armadilha de Shannon (SHANNON 1939): visa o conhecimento da composição faunistica, sazonalidade e atividade horária dos culicídeos. Foi executada por um coletor; em dois pontos (Estrada de asfalto e Carcará), permite selecionar amostras representativas de várias espécies antropofilicas, próprias do ecótopo. Por ter luz como estímulo atrativo, foi somente utilizada em horário predominantemente noturno, (das $17 \mathrm{~h}$ às $20 \mathrm{~h}$ ). Totalizando 03 horas de funcionamento.

Imaturos foram coletados em criadouros naturais pelo método de conchadas. Foram padronizadas 50 conchadas dentro de um transecto de $2 \mathrm{~m}^{2}$. Quaisquer larvas ou pupas de culicideos presentes nos criadouros examinados (Lagoa I e Lagoa II) foram transportadas vivas para o laboratório, onde foram criadas até as formas adultas. As formas imaturas mortas durante seu desenvolvimento foram montadas em lâminas para identificação.

\section{4 Área de estudo - Barragem de Biritiba (Croqui)}




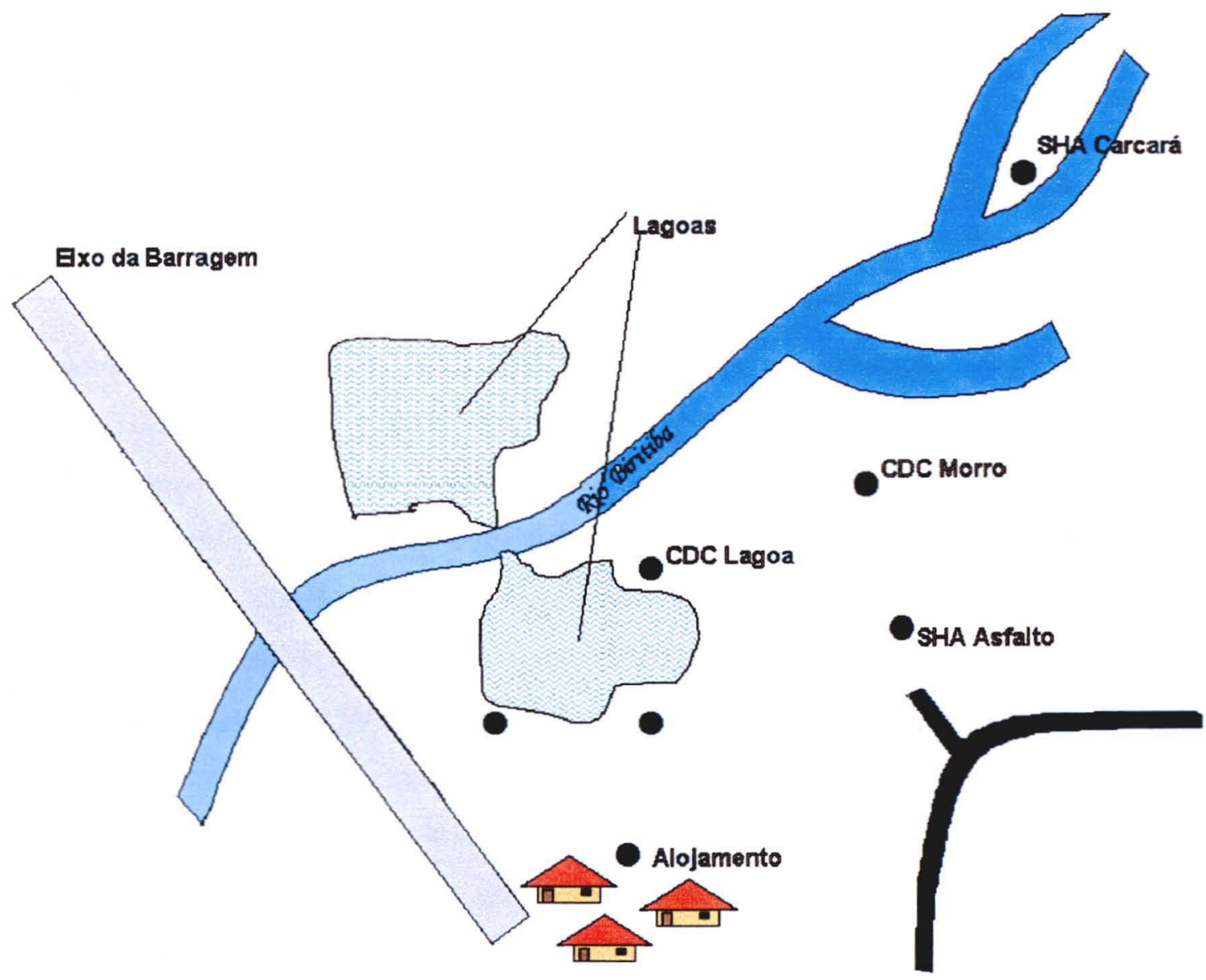

Figura 4. Croqui destacando os sítios de coleta.

\subsection{Período de Coleta}

Nos meses de Maio e Junho/02, foram realizadas viagens de campo para reconhecimento do local e definir pontos adequados para as coletas. Coletas piloto foram realizadas para obtenção dos principais gêneros da fauna de culicídeos. Os exemplares obtidos nas coletas piloto foram identificados e descartados não constando em tabela.

As expedições e viagens que visam o levantamento das espécies foram de caráter semanal, a partir de Julho/02 à Junho/03, onde foram realizadas coletas de adultos com armadilhas luminosas tipo Shannon em dois pontos fixos durante o horário das $17 \mathrm{~h}$ às $20 \mathrm{~h}$, compreendendo o horário de crepúsculo (Carcará 
388444/UTM7384823 e Estrada de asfalto 388539/UTM7388894). Tais capturas foram efetuadas por uma só pessoa, que coletava os mosquitos em toda superficie das barracas, utilizando tubo mortífero embebido em clorofórmio.

Foi utilizada também a armadilha CDC + gás carbônico em dois pontos fixos (Lagoa 388541/UTM7388890 e Morro 388678/UTM7388744) durante o intervalo das $17 \mathrm{~h}$ às $9 \mathrm{~h}$, estas armadilhas foram instaladas a $1,5 \mathrm{~m}$ de altura do solo.

Os adultos coletados foram mortos em atmosfera de clorofórmio e acondicionados em caixas entomológicas devidamente etiquetadas, revestidas com mistura de naftalina e parafina para sua conservação e finalmente enviados ao Laboratório de Entomologia da Faculdade de Saúde Pública - USP.

O trabalho realizado com os exemplares imaturos consistiu em coleta, desenvolvimento das larvas e pupas em laboratório para obtenção de exemplares adultos. Os imaturos que não completaram seu desenvolvimento foram fixados, corados e montados em lâmina e lamínula.

A coleta de imaturos, foi realizada em dois pontos (Lagoa I 388708/UTM7388914 e Lagoa II 388709/UTM7388935) nas margens de uma lagoa formada pelo rio Biritiba-Mirim, utilizou-se conchas com volume de $500 \mathrm{ml}$ em um quadrante $2 \times 2 \mathrm{~m}$ no período que antecede a devastação da área a ser inundada .

A unidade (UTM) de Geo-referenciamento foi adotada por ser a mesma utilizada nos mapas cedidos pelo DAEE.

A identificação foi efetuada até as categorias taxonômicas de gênero e/ou espécie, utilizando-se descrições e chaves taxonômicas (LANE 1953 a; LANE 1953 b; FORATTINI 1965a; FORATTINI 2002; SALLUM e FORATTINI 1996; CONSOLI e LOURENÇO DE OLIVEIRA 1994) e confronto com material padrão.

Os mosquitos identificados foram registrados em fichas de laboratório, contendo dados codificados correspondendo à espécie, ao sexo, e quantidade. Após esta identificação, uma amostra foi depositada em material testemunho. 


\subsection{Análise dos dados}

\subsubsection{Cálculo das médias horárias}

As médias horárias $(\mathrm{Xh})$ foram calculadas pela relação do total de culicídeos coletados segundo habitat, técnicas de coleta, total de horas gastas no período pesquisado.

\subsection{2 Índice de Abundância}

Para estimar a abundância numérica e distribuição temporal de cada uma das espécies de culicídeos coletados utilizando diversas técnicas, calculou-se o Índice de Abundância de Espécie (IAE), conforme ROBERTS e HSI (1979). Para se calcular esse índice, organizam-se os dados em uma planilha dispondo-se as espécies por ponto de coleta. Preenchem-se as células com valores numéricos representados pela quantidade de exemplares capturados. A partir da tabela original, gera-se uma segunda tabela onde os valores numéricos são transformados em posiçø̃es (ranking). Dessa forma, para cada ponto de coleta teremos o ordenamento das espécies segundo a posição conseqüente de sua quantidade.

\section{$\mathbf{I A E}=\mathbf{a}+\mathbf{R J} / \mathbf{K}$}

Onde:

$\mathrm{a}=$ Número de células brancas $\times \mathrm{C}$ (posição mais alta +1 )

$\mathrm{RJ}=$ somatória das posições por espécie

$\mathrm{K}=$ número de pontos de coleta

A padronização dos valores do IAE, para uma escala entre 0 e 1 , realizou-se através da obtenção do Índice de Abundância de Espécie Padronizado (IAEP) conforme a relação apresentada a seguir:

\section{IAEP=C - IAE/C-1}


Onde:

$\mathrm{C}=$ Posição mais alta +1 .

$\mathrm{IAE}=$ Índice de Abundância de Espécies.

\subsection{3 Índice de diversidade}

Para avaliar a diversidade de espécies nos pontos de coleta, foi calculado o Índice de Diversidade (IDv) para as espécies coletadas. Conforme MAGURRAM (1988).

$$
\mathrm{IDv}=\mathrm{S}-1 / \log _{\boldsymbol{e}} \mathrm{N}
$$

Onde:

$\mathrm{S}=$ número de espécies.

$\mathrm{N}=$ número de indivíduos.

\subsection{4 Índice de dominância}

Para conhecer a dominância das espécies, calculou-se o Índice de Dominância (IDo) de acordo com Berger-Parker.

Exprime a influência exercida por uma espécie em uma comunidade. Uma espécie pode ser pouco abundante, contudo exercer uma ação mais importante sobre a comunidade que uma espécie mais abundante, porém menor ou menos ativa.

\section{$\mathrm{ID}_{0}=\mathbf{N m a x} / \mathbf{N}$ total $\times 100$}

Onde:

Nmax = número de espécimens capturados da espécie mais freqüente.

Ntotal $=$ total de espécimens capturados. 


\subsubsection{Quociente de similaridade}

O Quociente de Similaridade (QS), citado por SERVICE (1993) foi calculado para comparar a distribuição de espécies nos dois ambientes pesquisados de cada técnica; conforme a fórmula a seguir:

$Q S=2 J / a+b$

Onde:

$\mathrm{J}=$ número de espécies que ocorrem nas duas coletas simultaneamente.

$\mathrm{a}+\mathrm{b}=$ número de espécies encontradas em ambas coletas separadamente.

\subsubsection{Constância das espécies}

Constância é a relação expressa em forma de porcentagem.

\section{$C=p \times 100 / P$}

Onde:

$\mathrm{p}=\mathrm{o}$ número de coletas contendo a espécie estudada

$\mathrm{P}=\mathrm{o}$ número total de coletas efetuadas

Segundo (Dajoz 1973) a constância das espécies é classificada por espécies dominantes, acessórias ou acidentais, onde:

Espécies constantes estão presentes em mais de $50 \%$ das coletas.

Espécies acessórias estão presentes em 25 a $50 \%$ das coletas.

Espécies acidentais estão presentes em menos de $25 \%$ das coletas. 


\subsection{Levantamento de dados meteorológicos}

Os dados de pluviosidade média mensal ( $\mathrm{mm}$ de chuva) e temperatura do ar média mensal $\left({ }^{\circ} \mathrm{C}\right)$, foram adquiridos no Departamento de Água e energia Elétrica (DAEE 2004; CCN 1997).

$\begin{array}{lc}\text { Temperatura*: } & 21,52^{\circ} \mathrm{C} \\ \text { Regime dos ventos*: } & 7 \mathrm{Km} / \mathrm{h} \text { (sentido S) } \\ \text { Pluviosidade*: } & 104,5 \mathrm{~mm} \\ \text { Altitude: } & 760 \mathrm{~m}\end{array}$

*(Valores escritos em Média anual) 


\section{RESULTADOS}

Foram identificadas 71 espécies de culicídeos distribuídos em 15 gêneros. Obteve-se um total de 8.139 mosquitos. Onde 4.435 foram capturados em Armadilha de Shannon, 3.388 foram capturados em armadilha luminosa CDC e 316 imaturos capturados utilizando a técnica de Conchadas.

Em todas as técnicas usadas prevaleceu maior número de fềmeas do que machos, totalizando: 7.648 fềmeas e 175 machos (316 imaturos).

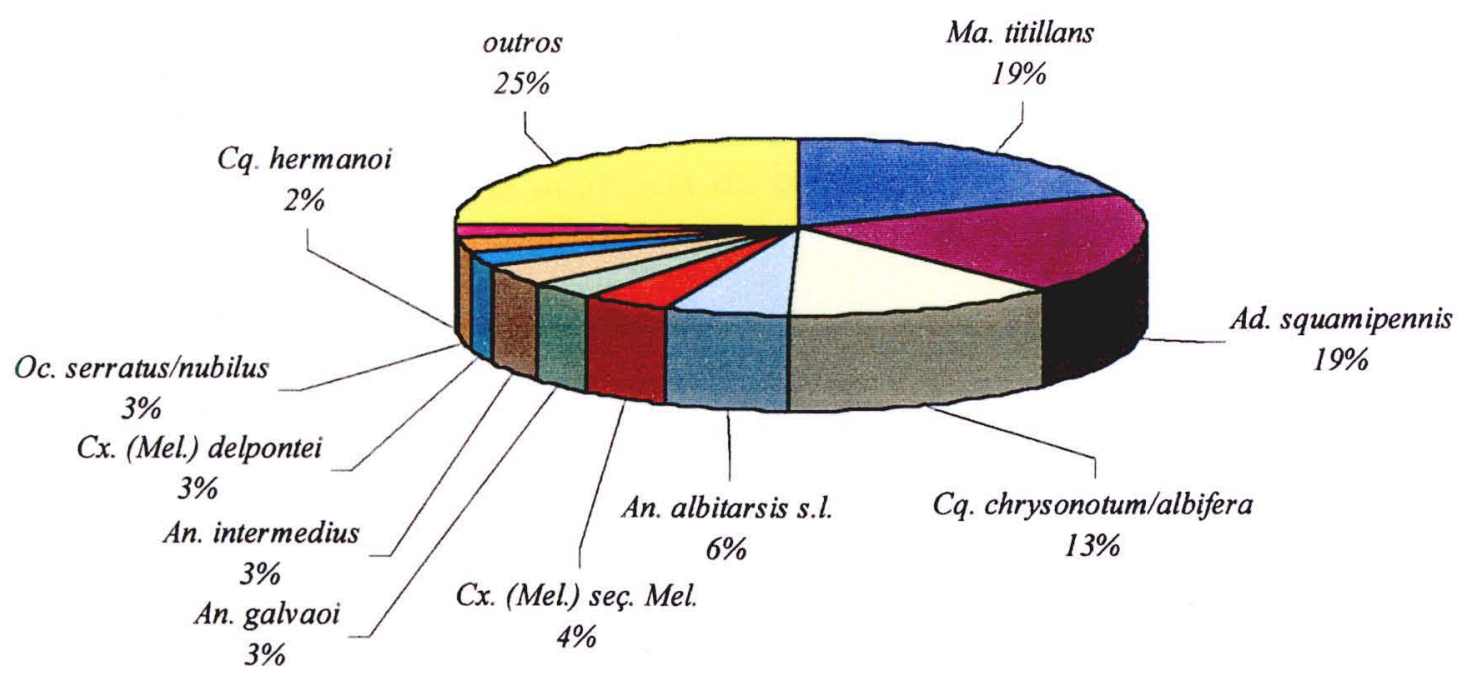

Figura 5: Espécies mais freqüentes, utilizando três técnicas, em área de influência da barragem de Biritiba-Mirim, São Paulo, Julho de 2002 a Junho de 2003.

As espécies Ad. squamipennis, An. albitarsis s.l., Cx. (Cux.) sp., Cx. (Mel.) seç. Mel., Ma. titillans, Cx. (Cux.) gr. Coronator, An. galvaoi ocorreram em todos os meses de coleta. 


\subsection{Média horária}

Tabela 1: Médias horárias (Xh) e densidade larvária de culicídeos coletados em três técnicas de captura na barragem de Biritiba-Mirim, São Paulo, Julho de 2002 a Junho de 2003.

\begin{tabular}{lccc}
\hline TEcnica & (No) & $(\%)$ & $(\mathrm{X} \mathrm{H})$ \\
\hline Shannon & 4435 & 54,5 & 14,8 mosquitos / h \\
CDC & 3388 & 41,6 & 2,1 mosquitos / h \\
T\&c. de conchadas & 316 & 3,9 & 0,06 imaturos / conchada \\
\hline Total & 8139 & 100 & \\
\hline
\end{tabular}

Dos 8.139 mosquitos capturados, 1136 exemplares são pertencentes ao gênero Anopheles, representando $14 \%$ do total de mosquitos.

Tabela 2: Caracterização dos vetores segundo importância epidemiológica: Área de influência da barragem de Biritiba-Mirim, São Paulo, Julho de 2002 a Junho de 2003.

\begin{tabular}{|lcc|}
\hline \multicolumn{1}{|c}{ Espécie } & N$^{\circ}$ Exemplares & Caracterização dos Vetores \\
\hline An. (Nys.) albitarsis & 482 & Primário \\
Na. (Ker.) cruzii & 4 & Primário \\
Na. (Nys.) galvaoi & 280 & Secundário \\
Na. (Nys.) triannulatus & 47 & Secundário \\
An. (Nys.) lutzi & 9 & Secundário \\
An. (Nys.) parvus & 1 & Secundário \\
An. (Ano.) intermedius & 274 & Secundário \\
An. (Nys.) evansae & 39 & Secundário \\
\hline
\end{tabular}

(Rachou 1958) 
Tabela 3 - Mosquitos adultos e imaturos coletedos utilizando 3 tocnicas em irea de Influencia de Barragem BirtibsGinim, 8p - Perlodo Julhora02 \& Junhorzo03.

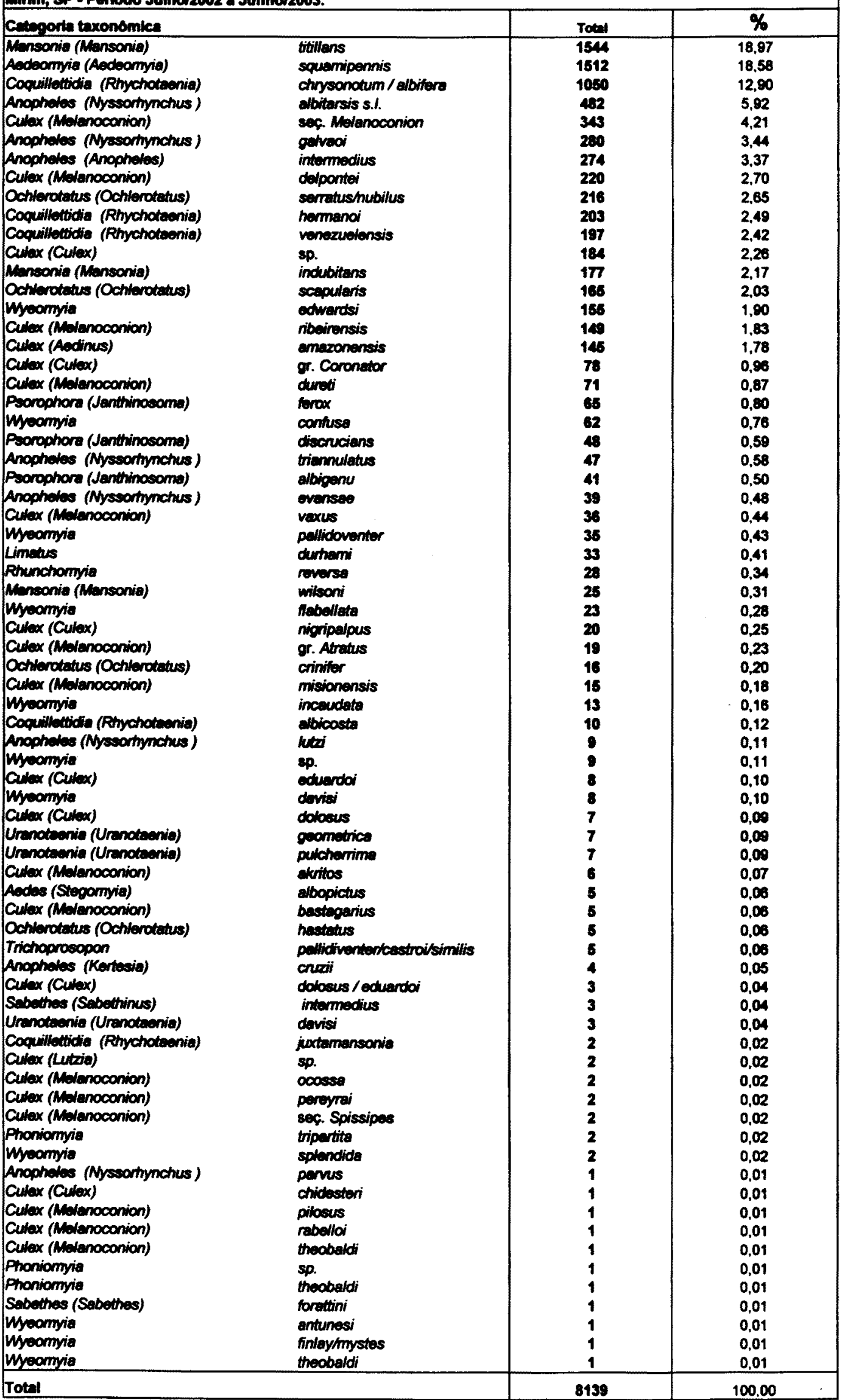




\subsection{Dados climatológicos}

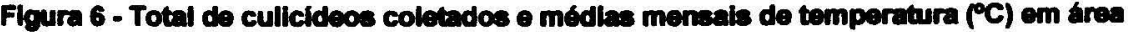
do Imfuêncla da barragem de Bifttbo-Mirim, Julho/2002 a junho/2003

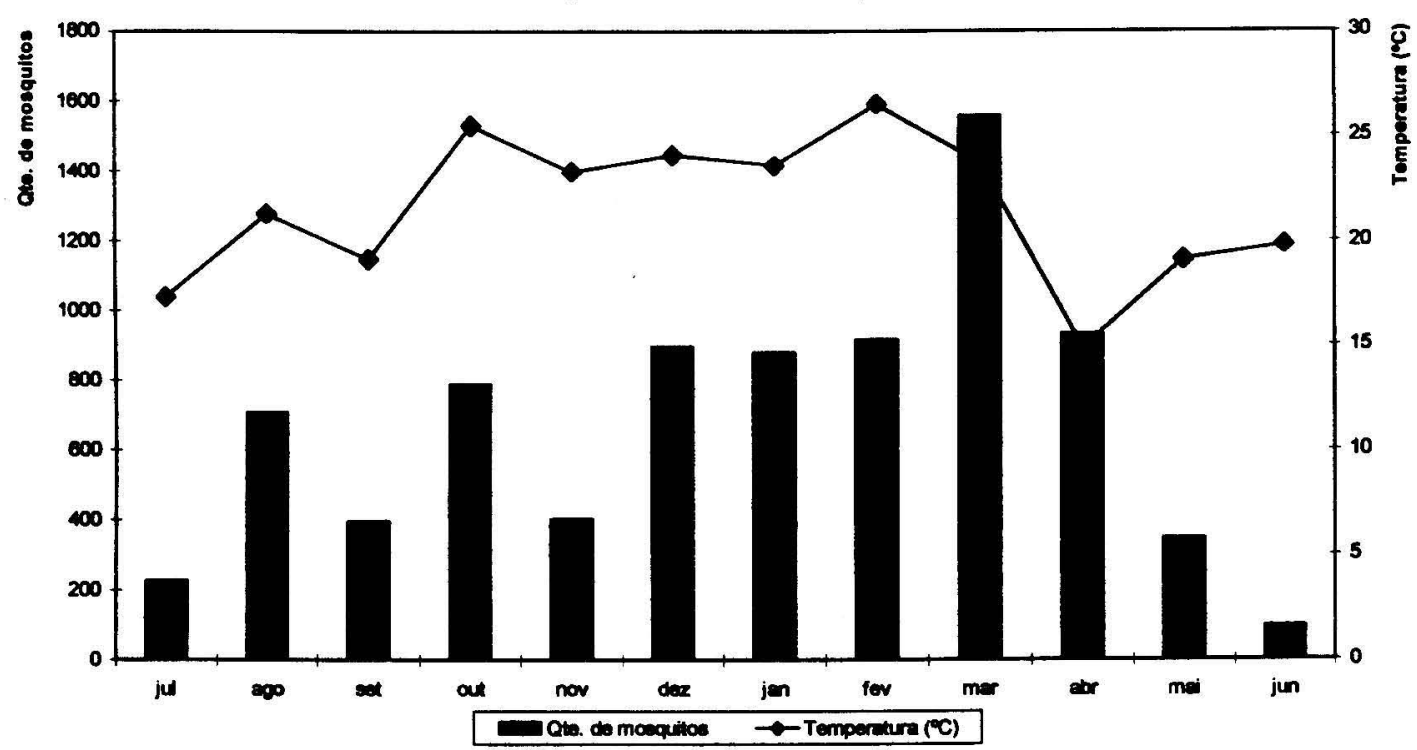

Figure 7 - Total de culleideos coletados e modias mensais de pluviosidade $(\mathrm{mm})$ em área de Infiuesncla da barragem de Birttiba-Mirim, juiho/2002 a junho/2003

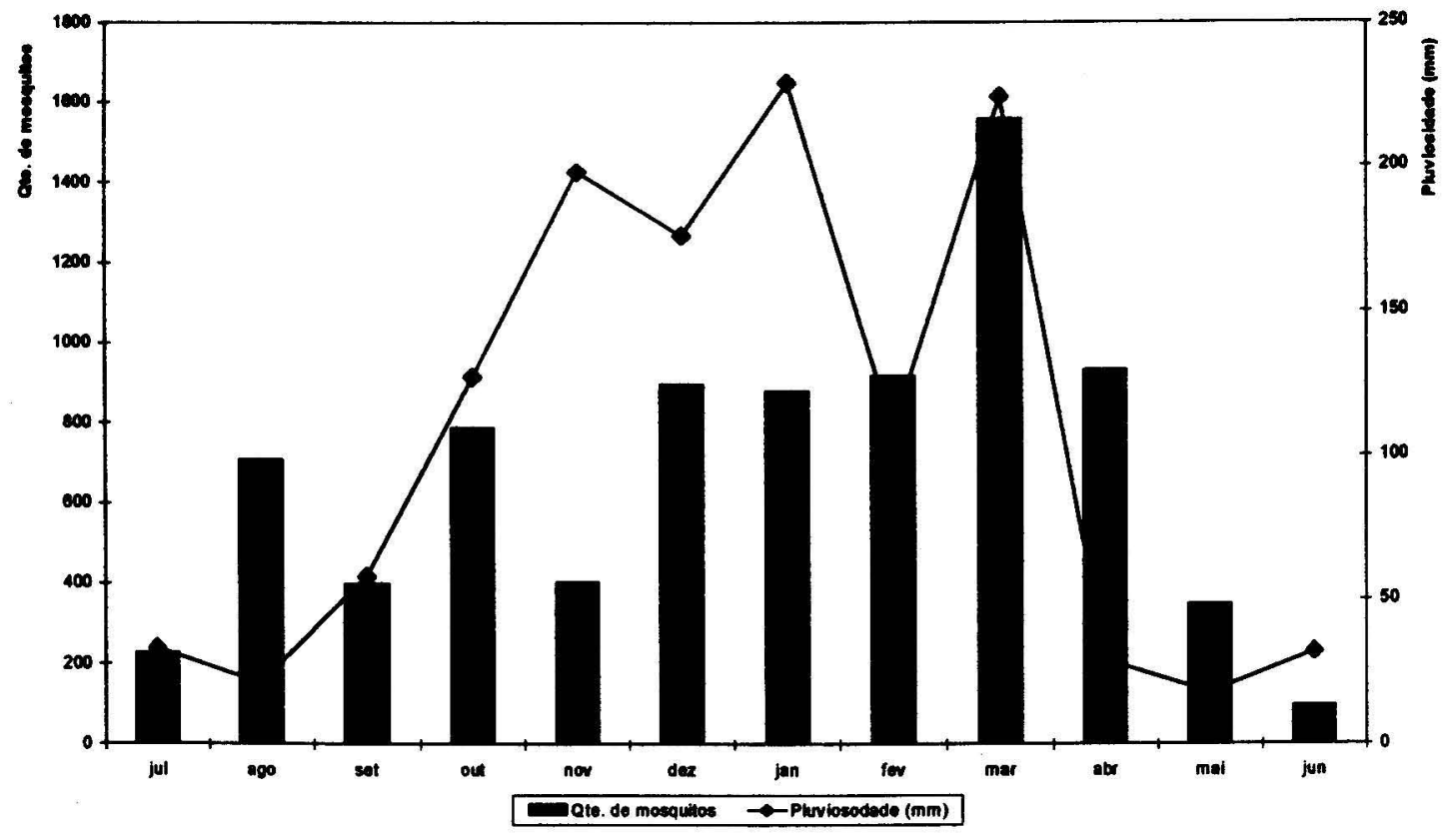




\section{3 Índice de abundância}

Tabela 4: Estimativa do Índice de Abundância dos mosquitos coletados em Armadilha CDC em área de abrangência da Barragem Biritiba-Mirim no período de Julho/2002 a Junho/2003.

\begin{tabular}{|c|c|c|c|c|c|c|c|c|c|c|c|c|c|c|c|c|c|}
\hline Categonia espectices & jut & 190 & Sot & Out & nov & dez & jan & fov & mar & $a b r$ & mal & jun & $\overline{\mathbf{R j}}$ & $a$ & UAE & LAEP & posiciso \\
\hline Ma. Gritans & 5 & 4 & 1 & 1 & 4 & 3 & 2 & 2 & 1 & 2 & 2 & 4,5 & 31,5 & 0,0 & 2,685 & 0,9293 & 10 \\
\hline Ad. squeniponnis & 7 & 3 & 3 & 3 & 1 & 1 & 7 & 1 & 5 & 1 & 5 & 1 & 32,0 & 0,0 & 2,667 & 0,9275 & $2^{*}$ \\
\hline An. slowntis s.i. & 9 & 1 & 2 & 2 & 8 & 6 & 5 & 11,5 & 9 & 10,5 & 4 & 4,5 & 6,6 & 0,0 & 5,373 & $0,00 \times$ & $3^{6}$ \\
\hline Cx. (na) exe Mal. & 4 & 7 & 9 & 18 & 8 & 7 & 9 & 3 & 2 & 4 & 1 & 2 & 72,0 & 0,0 & 6,000 & 0,706 & 40 \\
\hline An. intimmedius & 2 & 2 & 9 & 7 & 4 & 2 & 8 & 17,5 & 47,5 & 6 & 9,5 & 7 & 92,5 & 0,0 & 7,708 & 0,603 & $5^{\circ}$ \\
\hline Cxi(cix.) sp. & 7 & 8,5 & 11,5 & 5,5 & 12 & 5 & 8 & 7 & 8 & 9 & 6 & 4,5 & $\boldsymbol{2 3 , 0}$ & 0,0 & 7,750 & 0,7065 & 6 \\
\hline 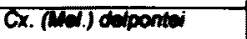 & 11 & 10 & 9 & 14 & 10,5 & 4 & 3 & 15 & 3 & 5 & 3 & & 87,5 & 24,0 & 9292 & $0,63 \%$ & 70 \\
\hline Cx. (Nat) niboironsis & & 5 & 91,5 & 14 & 2 & 8 & & 5 & 8 & 14,5 & 14 & 4,5 & 84,5 & 48,0 & 11,042 & 0,5634 & 8 \\
\hline An. gavied & 3 & 8,5 & 6 & 8,5 & & 12 & & 17,5 & 17,5 & 18 & 9,5 & & 9,5 & 72,0 & 14,292 & 0,421 & 9 \\
\hline Cq. chrreonotumbalbitert & & & & 18 & 10,5 & 10,5 & 4 & 6 & 14,5 & 3 & 14 & & 80,6 & 86,0 & 14,703 & 0,4040 & $10^{\circ}$ \\
\hline Cq. vennzualensis & 11 & 12,5 & 4 & 4 & 4 & 13 & & 9,5 & 23 & & & & 81,0 & 86,0 & 14,750 & 0,4000 & $11^{\circ}$ \\
\hline Oc. scapularis & 7 & 15,5 & & 8,5 & & 15 & 8 & 9,5 & 12,5 & 7 & & & 82,0 & 86,0 & 14,833 & 0,3966 & $12^{\circ}$ \\
\hline Me hodubitans & 11 & 11 & 6 & 5,5 & & 17 & & & 7 & & 7,5 & & 85,0 & 120,0 & 15,47 & 0,3732 & 130 \\
\hline Cx. (Cux.) or. Coronator & & & 6 & 8 & 6 & 8 & & 15 & 17,5 & & 14 & & 75,5 & 120,0 & 16292 & 0,3351 & $14^{\circ}$ \\
\hline Cx. (Ack.) am aronensis & 11 & 12,5 & & & & & & 4 & 4 & $\mathbf{1 2 , 5}$ & 14 & & 58,0 & 144,0 & 16,833 & 0,3116 & 15 \\
\hline Cq. harmanoi & & & & & & & & & 90 & 8 & 7,5 & & 25,5 & 216,0 & 20,123 & 0,1635 & $10^{\circ}$ \\
\hline An. crenseses & 11 & 14 & & 12 & & & & 15 & & & & & 52,0 & 192,0 & 20,333 & 0,159 & 17 \\
\hline Cx. (rial) vaxus & & 6 & & $\pi$ & & & & 11,5 & & & & & 28,5 & 216,0 & 20,375 & 0,1576 & $10^{\circ}$ \\
\hline Ps. Wbignu & & & & & & 10,5 & 9 & & 11 & & & & 30,5 & 216,0 & 20,542 & 0,1504 & $10^{\circ}$ \\
\hline Cx. (ival)er. Atratus & & & & & & 14 & 13 & 8 & 20 & & & & 55,0 & 192,0 & $20,5.3$ & 0,1486 & $20^{\circ}$ \\
\hline Oc. somiushubilus & & & & 18 & 13,5 & & & & 23 & 10,5 & 14 & & 79,0 & 168,0 & 20,553 & 0,1486 & $20^{\circ}$ \\
\hline Ps. discruciens & & & & 18 & 8 & & & & & 12,6 & & & 38,5 & 216,0 & 21,206 & 0,1214 & 22 \\
\hline Ponax & & & & & 13,5 & 17 & 8 & & & & & & 30,5 & 216,0 & 21,292 & Q1178 & $23^{\circ}$ \\
\hline Wh. wisoni & & & & 14 & & & & & 12,5 & & & & 26,5 & 240,0 & 2,200 & 0,079 & $26^{\circ}$ \\
\hline Cx. (cix.) nigipdipus & & & & & & & & $\overline{13}$ & 17,5 & & & & 30,5 & 240,0 & $2,3 \times 2$ & 0,0634 & $25^{\circ}$ \\
\hline Ur. perctenina & & & & & & 17 & & & 14,6 & & & & 31,5 & 240,0 & 22,68 & 0,058 & $20^{\circ}$ \\
\hline Oc. cringin & & & & & & & & & 23 & & 11 & & 34,0 & 240,0 & 22,833 & 0,0507 & $27^{\circ}$ \\
\hline An. pamas & & & 11,5 & & & & & & & & & & 11,5 & 204,0 & 22,958 & 0,0453 & $20^{\circ}$ \\
\hline Cx. (nal) alutos & & & 11,5 & & & & & & & & & & 11,5 & 204,0 & 22,958 & 0,0453 & 28 \\
\hline Ur. poomctrice & & 15,5 & & & & & & 21 & 23 & & & & 50,5 & 216,0 & 22,958 & 0,0453 & $\overline{26^{\circ}}$ \\
\hline Cx. (Cix.) dobosus & & & & & & & 13 & & & & & & 13,0 & 204,0 & 2,003 & 0,0399 & $31^{\circ}$ \\
\hline$C x .($ wal raballot & & & & & & & 13 & & & & & & 13,0 & 204,0 & 23,063 & 0,0399 & $31^{\circ}$ \\
\hline 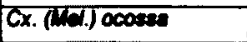 & & & & & & & & & & 14,6 & & & 14,6 & 204,0 & 23,208 & 0,0344 & $33^{\circ}$ \\
\hline Cx. (mal) pllosus & & & & & 15 & & & & & & & & 15.0 & 240 & 23,20 & 0,0326 & $34^{\circ}$ \\
\hline Cx. (nen.) perowni & & & & & & & & 21 & 23 & & & & 44,0 & 240,0 & $\mathbf{2 3 , 6 6 7}$ & 0,0145 & $35^{\circ}$ \\
\hline Cx. (We.) bastagerius & & & & & & & & 21 & & & & & 21,0 & 284,0 & 23,750 & 0,0109 & $\overline{30^{\circ}}$ \\
\hline Cx. (Na) a duredi & & & & & & & & 21 & & & & & 21,0 & 284,0 & 23,750 & 0,0109 & $30^{\circ}$ \\
\hline Ru. noverse & & & & & & & & $\overline{21}$ & & & & & 21,0 & 224,0 & 23,750 & 0,0109 & $38^{\circ}$ \\
\hline
\end{tabular}


Tabela 5: Estimativa do Índice de Abundância dos mosquitos coletados em Armadilha de Shannon em área de abrangência da Barragem Biritiba-Mirim no período de Julho/2002 a Junho/2003.

\begin{tabular}{|c|c|c|c|c|c|c|c|c|c|c|c|c|c|c|c|c|c|}
\hline Ceteporia texonomica & jull & $\infty 90$ & $20 t$ & out & nov & $\cos$ & $j e n$ & Fev & $\operatorname{mar}$ & $a b r$ & $\mathrm{~m} \approx$ & jun & $R_{i j}$ &. & TAE & UEP & promiono \\
\hline Mo. 确ons & 3 & 4 & 1 & 1 & 1 & 1 & 2 & 2 & 2 & 4 & 4 & 6 & 31,0 & 0.0 & 2,583 & 0,954 & 10 \\
\hline An. gineai & $T$ & 1 & 2 & 10,5 & 7,5 & & 22,5 & $\pi 1,5$ & 9,5 & $\overline{7,5}$ & 8 & 2 & 83,0 & 35,5 & 9,873 & 0.743 & $2^{\circ}$ \\
\hline Cq. chysonotum/atbilure & & & 23 & 2 & 2 & 2 & 1 & 1 & 1 & 1 & 1 & & 34,0 & 100,5 & 11,703 & 0,690 & $3^{\circ}$ \\
\hline Ad. squamipennis & 11 & 13 & 7 & 3 & 12,5 & & & 3 & 18 & 2,5 & 3 & 1 & 74,0 & 71,0 & 12,063 & 0,679 & $\$$ \\
\hline Cx. (Cux.) sp. & 11 & 14,5 & 23 & 8 & 14,5 & 13,5 & 11,5 & 16 & 12,5 & 10 & 7 & $\overline{6}$ & 145,5 & 0,0 & 12,125 & 0,678 & $5^{\circ}$ \\
\hline Cq. Monozunionsis & 8 & 5 & 6 & 4 & 5 & 6 & 8 & 5 & 15 & & & & 62,0 & 108,5 & 14,042 & 0,62 & $6^{\circ}$ \\
\hline Ma. indubtans & 4 & 11,5 & 4,5 & 5 & & 3 & & 7,5 & 4 & 17,5 & & 8 & 63,0 & 106,5 & 14,125 & 0,620 & $7^{\circ}$ \\
\hline Oc. semitushubifus & & & & & 4 & 4 & 4 & 7,5 & 12,5 & 2,5 & 2 & 8 & 44.5 & 142,0 & 13,542 & 0,579 & 8 \\
\hline An. alothris s.l. & 2 & 2 & 3 & 10,5 & & & 22,5 & 23,5 & 19,5 & 24 & 12 & 3,5 & 122,5 & 71,0 & 16,125 & 0,562 & 8 \\
\hline Wy. Givendsi & & 10 & 15,5 & 7 & 7,5 & 13,5 & 3 & 4 & 16,5 & 11 & & & 82,0 & 100,5 & 16,208 & 0,559 & 10 \\
\hline oc. eceputenis & & 14,6 & & 17 & 7.5 & 13.5 & 10 & 6 & 5 & 7,5 & 12 & & 90,0 & 108,5 & 16,625 & 0,547 & $11^{\circ}$ \\
\hline 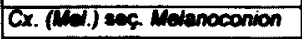 & 15 & 7 & 4,5 & 10,5 & 18 & & 13 & 19.5 & 7 & 17,5 & & & 112,0 & 106,5 & 18,208 & 0,501 & 12 \\
\hline Cx. (Cux.) F. Coronator & 5 & 7 & 8 & & 12,5 & & 14,5 & 19,5 & 27,5 & & 16 & 9 & 120,0 & 400,5 & 18,875 & 0,462 & $13^{\circ}$ \\
\hline Wy.conture & & 11,5 & 15,5 & 22,5 & 18 & & 7 & 11,8 & 12,5 & 12,5 & & & 111,0 & 142,0 & $21,0.3$ & 0,418 & 140 \\
\hline An. intomedius & 8 & 3 & 23 & 8 & 18 & & & & 31,6 & & 10 & & $\infty, 5$ & 177,5 & 20,003 & 0,360 & $15^{*}$ \\
\hline Cx. (na) nboinentis & 16 & 7 & 8 & 10 & & & 22,5 & 19,6 & 24,6 & 24 & & & 130,5 & 142,0 & 23,458 & 0,349 & $16^{\circ}$ \\
\hline Ps. Frox & & 27 & & & 7,5 & 5 & 5 & 9 & 31,5 & 21 & & & 108,0 & 177,5 & 23,625 & 0,344 & $17^{\circ}$ \\
\hline An. ovansee & B & 7 & 11,5 & 15 & 24,5 & 17 & & 23,5 & & & & & 108,5 & 177,5 & 23,667 & 0,343 & 18 \\
\hline Cx. (Nel) dureti & & & & & 3 & & 22,5 & 16 & 8 & 12,5 & 12 & & 72,0 & 213,0 & 23,750 & 0,341 & $10^{\circ}$ \\
\hline Ca. hamanoi & & 27 & & & & & & & 3 & 5 & 5 & 11 & 51,0 & 248,5 & 24,958 & $\overline{0,306}$ & $20^{\circ}$ \\
\hline Ru. Roverse & & 21 & & & & & 11,5 & 14 & 19.5 & 17.5 & & 11 & 94.5 & 213,0 & 25,625 & 0,286 & $21^{\circ}$ \\
\hline An. triannulatus & & & & & & & & 34,5 & 9,5 & 9 & 6 & 3.5 & 62,5 & 248,5 & 25,917 & 0,278 & $22^{\circ}$ \\
\hline Wy thollthe & & & & & 18 & 8 & 16,5 & 23,6 & 21,6 & 14 & & & 101,5 & 213,0 & 26200 & 0,269 & $23^{\circ}$ \\
\hline Cx. (ciox.) nigripalpus & & $\overline{21}$ & 15.5 & & & & & 28 & 21,5 & & 16 & 11 & 113,0 & 213,0 & 27,167 & 0,242 & $24^{\circ}$ \\
\hline L. duthami & & & & & & 10 & 9 & 10 & 24,6 & 24 & & & 77,5 & 248,5 & 27,167 & 0,242 & $24^{\circ}$ \\
\hline Po. ebronu & & & & & 24,5 & 10 & 16 & 19,5 & 24,5 & & & & 94.5 & 240,5 & 28,503 & 0,200 & 25 \\
\hline Me. witeon & 8 & 27 & 10 & & & & & & 16,6 & & & & 61,5 & 284,0 & 23,792 & 0,194 & $20^{\circ}$ \\
\hline Wh. hendat & & & & 22,5 & 11 & 7 & 22,5 & & & & & & 63,0 & 284,0 & 20,917 & 0,191 & $27^{\circ}$ \\
\hline De. crininar & & 18 & & 19 & 14,5 & & & & & 15 & & & 60,5 & 284,0 & 29,200 & 0,18 & $28^{\circ}$ \\
\hline Pr. diforcians & & & & & 18 & & & 34,5 & & 8 & 9 & & 67,5 & 284,0 & 29,292 & 0,180 & $29^{\circ}$ \\
\hline Cx. (nal) misionensis & & 18 & & 10,8 & 24,5 & & & 28 & 24,6 & & & & 106,5 & 248,5 & 20,500 & 0,174 & 30 \\
\hline Cx. (mel) dalpontai & & 27 & 23 & 22,5 & & & 22,5 & & 12,6 & & & & 107,5 & 248,5 & 29,667 & 0,169 & $31^{\circ}$ \\
\hline Cx. (Mdd) Emanonensis & & & 11,5 & & & & & 34,5 & 8 & 21 & & & 75,0 & 204,0 & 29,917 & 0,162 & $32^{\circ}$ \\
\hline W. dovial & & 21 & & & & 17 & 14,6 & 28 & & & & & 80,5 & 284,0 & 30,375 & 0,149 & $33^{\circ}$ \\
\hline An.kn & & 18 & 15,5 & 15 & & & & & & & & & 48,5 & 319.6 & 30,667 & 0,140 & 340 \\
\hline Oc. hactolus & 15 & 27 & 15,5 & & & & & & & 27,5 & & & 86.0 & 284,0 & 30,750 & 0,138 & 35 \\
\hline C4 aboos & & & & & 10 & 10 & & & & & & & 20,0 & 305,0 & 31,250 & 0,123 & $30^{\circ}$ \\
\hline Wy. peridowenter & & & & & & & 6 & 34,6 & 31,6 & 21 & & & 93,0 & 284,0 & 31,417 & 0,118 & $37^{\circ}$ \\
\hline C.x. (Cux.) doboens & & 27 & & 15 & 24,5 & & & & 31.6 & & & & 96,0 & 284,0 & 31,833 & 0,106 & $36^{\circ}$ \\
\hline Ur. dowit & 15 & & & 19 & & & & & & & & & 34,0 & 355,0 & 32,417 & 0,069 & $30^{\circ}$ \\
\hline Cx. (na) vaxus & & & 23 & 13 & & & & 34,5 & & & & & 70,5 & 319,5 & 32500 & 0,067 & $40^{\circ}$ \\
\hline Wy. Sp. & & & & & & 17 & & 27,5 & 27,5 & & & & 72,0 & 318,5 & 32,625 & 0,083 & $41^{\circ}$ \\
\hline Tr. princiventorteastroikimilis & & & & & & & 22,6 & 23,5 & & 27,5 & & & 73.5 & 310,6 & 32,750 & 0,030 & $42^{\circ}$ \\
\hline Ur. govomotrice & 11 & 27 & & & & & & & & & & & 38,0 & 355,0 & 32,750 & 0,000 & $42^{\circ}$ \\
\hline Cx. (nal) akritos & & 16 & & 22,5 & & & & & & & & & 38,5 & 356,0 & 32,792 & 0,079 & $43^{\circ}$ \\
\hline Ph. triperita & & 27 & & & & & & & & & 18 & & $\mathbf{4 3 , 0}$ & 355,0 & 33,167 & 0,068 & $44^{\circ}$ \\
\hline An. connin & & & 15.6 & & & & & 20 & & & & & $\mathbf{4 3 , 5}$ & 355,0 & 33,208 & 0,066 & 45 \\
\hline So. intermedius & & & & & 24,5 & & 22,5 & $\overline{34,5}$ & & & & & 81,5 & 318.6 & 33,417 & 0,060 & $46^{\circ}$ \\
\hline CX. (Wa.) bestagenius & & & 23 & & & & & 28 & 31,5 & & & & 82,5 & 310,5 & 33,500 & 0,058 & $47^{\circ}$ \\
\hline Cx. (Cux.) dablesushoduendoi & & & & & & 13,5 & & & & & & & 13,5 & 300.5 & 30,667 & 0,053 & $40^{\circ}$ \\
\hline C. (Ma). enc. Spistipos & & 27 & 23 & & & & & & & & & & 50,0 & 355,0 & 33,750 & 0,051 & $40^{\circ}$ \\
\hline Ur. putchertine & & 27 & 23 & & & & & & & & & & 50.0 & 355,0 & 33,750 & 0,051 & 40 \\
\hline Cx. (Lutria) sp. & 15 & & & & & & & & & & & & 15,0 & 300,5 & 33,792 & 0,050 & $50^{\circ}$ \\
\hline Cx. (Ma) or. Atratus & & & 23 & & & & & & & 27,5 & & & 50,5 & 355,0 & 33,792 & 0,050 & $50^{\circ}$ \\
\hline Cx. (Mel) chidosteri & & & & & & & & & & & 16 & & 16,0 & 390,5 & 33,875 & 0,047 & $51^{\circ}$ \\
\hline Ph. Sp. & & & & & & & & & & & 16 & & 16.0 & 380,5 & 33,875 & 0,047 & $51^{\circ}$ \\
\hline Wy. spiencide & & 27 & & & 24,5 & & & & & & & & 51.5 & 355,0 & 33,875 & 0,047 & $51^{\circ}$ \\
\hline AQ. Iboosictus & & & & & & & & 34,5 & & $\$ 7,5$ & & & 52,0 & 355,0 & 33,917 & 0,046 & $52^{\circ}$ \\
\hline Ca. juxtamansonia & & & & & 24,5 & & & & & 27,5 & & & 52,0 & 355,0 & 33,917 & 0,046 & $52^{\circ}$ \\
\hline Ph. theobedi & & & & & & & 22,5 & & & & & & 22,5 & 390,5 & 34,417 & 0,031 & $53^{\circ}$ \\
\hline Sa. forctinil & & & & & & & 22,5 & & & & & & 22,5 & 390,5 & 34,417 & 0,031 & $53^{\circ}$ \\
\hline Wy. hintaymyotes & & & & & 24,5 & & & & & & & & 24,5 & 390.5 & 34,583 & 0,027 & 50 \\
\hline Cx. (Wed.) theobald & & & & & & & & & 31,5 & & & & 31,5 & 390,5 & 35,167 & 0,010 & $55^{\circ}$ \\
\hline Wy. antunesi & & & & & & & & 34.5 & & & & & 34,5 & 390,5 & 35,417 & 0,002 & $50^{\circ}$ \\
\hline Wy. Heobahd & & & & & & & & 34,5 & & & & & 34,5 & 390,5 & 35,417 & 0,002 & $56^{\circ}$ \\
\hline
\end{tabular}




\section{4 Índice de diversidade}

O Índice de diversidade obtido neste estudo, onde 8139 culicídeos foram capturados é $\mathbf{7 , 7 8}$

Esta análise leva em conta a riqueza de espécies e a equitabilidade na repartição dos indivíduos entre as espécies. A diversidade pode ser definida como uma medida de composição de espécies de um ecossistema em termos de números e abundância relativa.

\section{5 İ́dice de dominância:}

A dominância exprime a influência exercida por uma espécie em uma comunidade. A seguir apresentamos os dados relativos à dominância, segundo técnica e sítios de coleta obtidos no presente estudo:

Armadilha de Shannon:

- Carcará: a espécie dominante foi $C q$. chrysonotum com $42,94 \%$.

- Estrada de asfalto: a espécie dominante foi Ma. titillans com 27, 87\%. Armadiliha CDC:

- Lagoa: a espécie dominante foi Ad. squamipennis com 35,78\%.

- Morro: a espécie dominante foi Ma. titillans com 21,44\%.

Coleta de Imaturos:

- Lagoa I: a espécie dominante foi $A d$. squamipennis com 77,54\%.

- Lagoa II: a espécie dominante foi Ad. squamipennis com 82,94\%.

\subsection{Quociente de similaridade}

Com a finalidade de comparar a fauna entre dois sítios de coleta foi utilizado o Índice de Sorensen. Obteve-se a seguinte similaridade:

- Armadilha de Shannon (Sítios de coleta Carcará e Estrada de asfalto): $\mathbf{7 7 \%}$

- Armadilha CDC (Sítios de coleta Lagoa e Morro): $\mathbf{7 7 \%}$

- Coleta de Imaturos (Sítios de coleta Lagoa I e Lagoa II): 55\% 


\subsection{Constância das espécies}

No presente estudo 71 espécies de culicídeos foram capturadas, das quais 19 são classificadas como constantes, 25 são classificadas como acessórias e 27 como espécies acidentais.

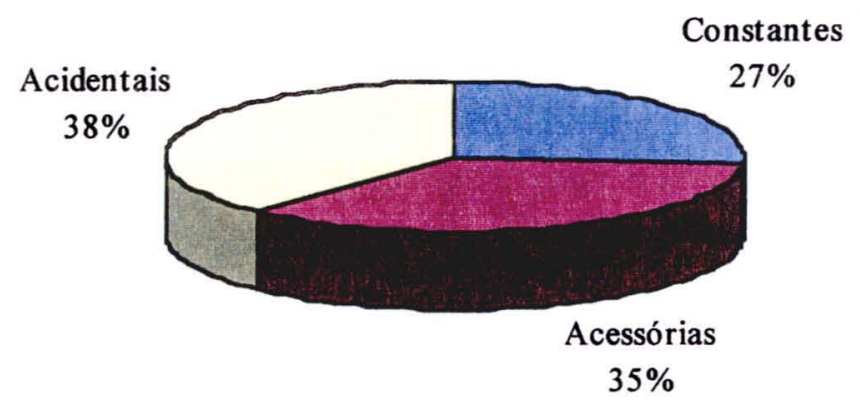

Figura 8: Distribuição das espécies segundo Constância em área de influência da barragem de Biritiba-Mirim, São Paulo, Julho de 2002 a Junho de 2003. 


\section{Analise dos Índices}

Diversidade

A diversidade pode ser definida como uma medida de composição de espécies de um ecossistema em termos de números e abundância relativa.

O Índice de diversidade obtido neste estudo, onde 8139 culicídeos foram capturados é 7,78.

Esta análise leva em conta a riqueza de espécies e a eqüitabilidade na repartição dos individuos entre as espécies.

\section{Abundância}

O Índice de Abundância das espécies proposto por ROBERTS \& HSI (1979) é utilizado para estimar a abundância numérica e distribuição temporal de cada uma das espécies de culicídeos coletados. Onde as espécies são dispostas em uma planilha em forma de "ranking".

As dez espécies mais abundantes coletadas em armadilha de Shannon foram: $\mathrm{Ma}$. titillans, An. galvaoi, Cq. chrysonotum, Ad. squamipennis, Cx. (Cux.) sp., Cq. venezuelensis, Ma. indubitans, Oc. serratus, An. albitarsis s.l.,Wy. edwadsi. As dez espécies mais abundantes coletadas em armadilha CDC foram: Ma. titillans, Ad. squamipennis An. albitarsis s. l., Cx. (Mel.)seç. Mel, An .intermedius, Cx. (Cux.) sp., Cx. (Mel.) delpontei,Cx.(Mel.)ribeirensis, An. galvaoi, Cq. Chrysonotum.

\section{Similaridade:}

Este índice evidencia a fauna compartilhada entre as técnicas utilizadas em dois sítios de coleta, onde o presente estudo obteve $77 \%$ para a armadilha de Shannon e CDC. Esta alta porcentagem é devida a grande proximidade dos ecótopos (10Km).

Alguns fatores que podem ter influenciado a diminuição deste índice são os fatores ambientais ecológicos e sazonais.

$\mathrm{Na}$ coleta de Imaturos o índice foi de $55 \%$. Esta baixa similaridade pode ser explicada pelo fato de um número muito reduzido de espécies $(8 s p)$ ter sido capturado.

Cada espécie exprime um grau elevado no conjunto, onde a ausência de alguma espécie mostra uma grande queda neste índice. 


\section{Constância:}

No presente estudo o número de espécies constantes $27 \%$, acessórias $25 \%$ e acidentais $38 \%$ se apresentou praticamente com igual distribuição. Podemos inferir que esta área possui uma alteração antropofilica acentuada. Segundo Dajoz 1973 uma área silvestre (conservada) deve apresentar uma elevada porcentagem de espécies acidentais (acima de $50 \%$ ).

Este índice tem como desvantagem o fato de sofrer influência do número de coletas, considera a presença de uma determinada espécie, mas não o número de indivíduos.

Dominância:

Este indice aponta a espécie dominante em todo período, mas é um índice tendencioso porque sofre a influência de uma explosão populacional.

A dominância exprime a influência exercida por uma espécie em uma comunidade. A seguir apresentamos os dados relativos à dominância, segundo técnica e sítios de coleta obtidos no presente estudo:

Armadilha de Shannon:

- Carcará: a espécie dominante foi Cq. chrysonotum com 42,94\%.

- Estrada de asfalto: a espécie dominante foi Ma. titillans com 27, 87\%. Armadilha CDC:

- Lagoa: a espécie dominante foi Ad. squamipennis com 35,78\%.

- Morro: a espécie dominante foi Ma. titillans com 21,44\%.

Coleta de Imaturos:

- Lagoa I: a espécie dominante foi $A d$. squamipennis com 77,54\%.

- Lagoa II: a espécie dominante foi Ad. squamipennis com 82,94\%. 


\section{DISCUSSÃO}

No início deste inventário as condições ambientais desta área de estudo se caracterizavam por ambiente silvestre alterado, devido ao impacto causado pelas obras de construção do eixo da barragem. No local onde se situava o canteiro de obras, se formou uma lagoa e esta deu origem a um grande criadouro permanente de culicídeos e esta sendo colonizada por plantas aquáticas em toda sua extensão.

Outro problema com relação à implantação de Lagos artificiais é o intenso assoreamento que pode ocorrer na represa em função da acumulação de sedimentos, provenientes das bacias de contribuição regionais, que se depositam ao chegar ao ambiente lêntico do reservatório.

$\mathrm{O}$ acúmulo de matéria orgânica e de minerais eutrofizantes nas reentrâncias ou braços da represa facilita o desenvolvimento de vegetação marginal e reduz a profundidade do espelho d' água a uns poucos centímetros, tornado-se um obstáculo à navegação promovendo o aquecimento da mesma e favorecendo a proliferação de mosquitos. (TEODORO et al. 1995; TADEI 1996).

DORVILLÉ (1996) agrupa os mosquitos em três classes que desempenham papel de bioindicadoras das açðes antrópicas. Anopheles que pertencem ao subgênero Kerteszia caracterizam ambientes naturais e conservados. Por outro lado mosquitos que se criam em buracos de árvores como os da Tribo Sabethini, indicam que o ambiente silvestre que sofreu algum tipo de alteração antrópica. Já a presença de mosquitos da Tribo Mansoniini indica ambientes com alto grau de antropização.

Segundo LOURENÇO-DE-OLIVEIRA (1985 b), ventos com velocidade aproximadamente de $24 \mathrm{~km} / \mathrm{h}$ nåo atrapalham o andamento das coletas de culicídeos. Esta região apresenta uma média anual de regime dos ventos de $7 \mathrm{~km} / \mathrm{h}$ e podemos inferir que foi desprezivel a interferência deste fator na atividade das espécies aqui estudadas.

Os mosquitos colocados em destaque neste item estão entre os adultos mais abundantes neste estudo ou apresentam algum interesse médico.

Neste estudo os exemplares da Tribo Mansoninii estiveram presentes em todas as coletas e se encontram no primeiro lugar no "ranking" de abundância das espécies, em ambos os sítios pesquisados, dando destaque para Mansonia titillans e Ma. indubitans, Coquillettidia chrysonotum, Cq. hermanoi e Cq. venezuelensis. 
DORVILLÉ (1995) cita que a população de imaturos de Mansoniini, no verão, prolifera devido ao grande aumento do nível de água nas áreas alagadas semipermanentes. E também aumentando a produção de macrófitas. Vista que estas larvas e pupas possuem apêndices respiratórios adaptados a perfurar tecidos (aerênquima) destas plantas aquáticas, para a obtenção do oxigênio necessário à sua respiração (FORATTINI 1965b).

Mansonia e Coquillettidia são mosquitos de ambientes florestais e de áreas alagadas (DORVILLÉ 1995). Possuem hematofagismo agressivo e são de comportamento eclético e oportunista, interferindo na pecuária e em outras atividades do homem em certas regiões. É no crepúsculo vespertino que atinge seu pico de hematofagia, mas possui atividade tanto diurna como noturna, é exófila, mas pode ser encontrada dentro de casas, atraída pela luz artificial ou mesmo pelos hospedeiros, mas não permanece no domicilio após o repasto. A invasão constante de domicílios depende da proximidade da casa ao criadouro, ocorrendo em todos os meses do ano, pois seus criadouros são perenes (KLEIN et al. 1992).

A exemplo disso, na área de influência da usina hidrelétrica de Tucuruí, com a intensa proliferação de Eichhornia spp. no Rio Tocantins-PA, centenas de familias abandonaram suas casas e lavouras, e as familias remanescentes sofreram com o ataque quase ininterrupto dos Mansoniini que se criaram no enorme lago da Hidrelétrica (CONSOLI e LOURENÇO-DE-OLIVEIRA 1994).

As fềmeas de Coquillettidia sp. são numerosas e agressivas como as de Mansonia, são ecléticas e oportunistas, picando a qualquer hora do dia e noite as mais variadas vítimas. $C q$. venezuelensis e $C q$. chrysonotum são destacadas na literatura, pois, ambas são vetoras potenciais de arboviroses, tendo sido encontradas naturalmente infectadas por Oropouche (CONSOLI E LOURENÇO DE OLIVEIRA 1994).

FORATTINI et al. (1986 a, b) assinalaram que a fauna de culicídeos de áreas submetidas a alterações ambientais pode sofrer impactos em conseqüência da destruição de seus ecótopos e da incapacidade de adaptação de determinadas espécies às condições surgidas. Ao mesmo tempo, outras espécies adaptam-se às áreas alteradas, proliferando-se intensamente, podendo causar incômodo ou transmitir doenças. As condições ambientais presentes em Biritiba favorecem a adaptação de 
varias espécies de culicídeos, principalmente a proliferação dos Gêneros Mansonia e Coquillettidia.

LOURENÇO-DE-OLIVEIRA (1985) afirma que Ma titillans é geralmente reconhecida como espécie crepuscular vespertina e noturna, esta característica foi observada durante nossas coletas.

Os adultos de $A d$. squamipennis também estiveram presentes em todos os meses pesquisados e foram capturados em grande escala em armadilha de Shannon e CDC, sendo o horário de maior atividade a partir das 18 horas, portanto, durante o crepúsculo vespertino. Esta espécie também se mostrou dominante nos criadouros pesquisados, representando $82,35 \%$ dos imaturos coletados.

Ad. squamipennis não possui hábitos antropofilicos, praticando hematofagia em aves e também são atraídos por fontes luminosas artificiais.

No presente estudo o pico de atividade destes mosquitos se deu nos períodos quentes-chuvosos, nos meses de dezembro a março.

As larvas de Ad. squamipennis apresentam um padrão específico de distribuição nos criadouros, encontrando-se em ambiente de água parada com abundante vegetação aquática e incidência solar direta (KRUIJF et al. 1973; CASANOVA 1994).

BARATA et al. (1993) encontram alto índice de positividade para imaturos de Ad. squamipennis em alagados nas margens das estradas, lagoas artificiais, córregos e pequenos criadouros próximos às habitações na Bacia do Rio Purus, Acre.

Os subgêneros de Anopheles encontrados foram Anopheles, Kerteszia e Nyssorhynchus, onde as espécies mais freqüentes foram An. albitarsis, An. galvaoi, An. intermedius. Foram coletados durante todo período de estudo, sua captura se deu a partir do segundo horário ( $18 \mathrm{~h}$ às $20 \mathrm{~h}$ ) com exceção do An. (Ano) intermedius que foi coletado principalmente no primeiro horário (17h às $18 \mathrm{~h}$ ).

Neste estudo sua captura foi freqüente em todos os meses do ano, porém sendo mais numerosos de janeiro a junho. Nos criadouros pesquisados o Anopheles albitarsis s. $l$. foi a segunda espécie no "ranking" de abundância.

O Anopheles albitarsis $s$. $l$. é considerado um complexo de espécies crípticas de taxonomia ainda pouco esclarecida, talvez por esse motivo seja um dos anofelinos relacionados com a transmissão de Malária humana que tem maior 
ecletismo em todos os aspectos de seus hábitos. Sua capacidade de invadir domicilio e sua elevada antropofilía fez com que fosse incriminado como vetor potencial em áreas onde ocorre, mas não de grande importância epidemiológica (XAVIER e REBÊLLO 1999).

Segundo FORATTINI (2002) o litoral do estado de São Paulo é constituído por áreas potenciais da transmissão da Malária, onde os vetores incriminados podem ser do Complexo Albitarsis.

TEODORO et al. (1995), em estudo de culicídeos do lago de Itaipú no Rio Paraná, encontraram An. albitarsis s.l. entre as espécies mais abundantes em armadilha de Shannon, comparecendo em todos os horários de captura, com maior atividade no crepúsculo vespertino.

O An. albitarsis sempre foi considerado como vetor primário, de maneira geral esse mosquito foi caracterizado por exercer este papel em vários pontos do litoral brasileiro (FORATTINI 2002).

DE PAULA (2001) e FORATTINI (2002) afirmam que os imaturos deste Gênero são abundantes nos alagadiços, nos cursos d'água doce e limpa, bem expostas ao sol e com presença de vegetação, podendo ser criadouros permanentes ou transitórios e de várias situaçőes de solo.

Dentre outras espécies capturadas deste Gênero, destacamos o An. triannulatus e que também está na lista das espécies suspeitas de transmitir malária no Brasil, porém neste estudo foi pouco freqüente. É uma espécie de hábito zoofilico e exofilico, que eventualmente ataca o homem em menor freqüência que a outros animais como equinos e bovinos (XAVIER e REBÊLO 1999).

DORVILLÉ (1995) cita que An. triannulatus cria-se em grandes coleções de água límpida, não salina, bem exposta ao sol, com abundante vegetação, como estações de brejo e poças semipermanentes, características apresentadas pelos criadouros pesquisados em nosso trabalho.

LOPES (2002) destaca que a plasticidade genética capacita espécies como An. albitarsis, An. evansae, An. strodei a colonizar desde ambientes silvestres até ambientes totalmente alterados. Assim, na construção de barragens, sua presença nas lagoas que se formam deve ser considerada, pois elas ampliam as oportunidades desses culicideos. De acordo com trabalho realizado por CONSOLIM et al. 1991 no 
lago da Hidrelétrica de Itaipu, alterações artificiais em um ecossistema, em áreas endêmicas, favoreceram a proliferação de vetores e a incidência de Malária.

An. galvaoi, An. evansae, An. strodei são zoofilicos e exófilicos e se infectam no auge de epidemias promovidas por vetores primários (CONSOLI e LOURENÇO-DE-OLIVEIRA 1994).

Foram capturados quatro exemplares de $A n$. (Ker.) cruzii em armadilha de Shannon (dois em cada sítio de coleta pesquisado) nos meses de setembro e fevereiro. Esta espécie é dotada de elevado interesse epidemiológico como vetor de malária na região de Mata Atlântica. (FORATTINI 2002).

A baixa densidade de $A$ n. cruzii confirma que esta regiåo apresenta alto grau de degradação ambiental, onde este anofelino desempenha papel de bio-indicador.

As características ecológicas e comportamentais do gênero Ochlerotatus observadas neste estudo foram concordantes com os autores citados a seguir, onde estes mosquitos foram capturados em maior escala nos meses quentes e chuvosos compreendidos entre dezembro/02 á março/03.

Oc. scapularis são considerados mosquitos de pequeno porte e as fêmeas são hematófagas vorazes, com aparente preferência em sugar mamíferos de grande porte, incluindo o homem. Esta atividade é predominantemente diurna, inclui algumas ações noturnas, porém é mais intensa nas horas de crepúsculo vespertino. (FORATTINI 2002)

Por utilizar criadouros naturais (poças d' água e alagados no solo) e artificiais (valas de drenagem, impressões de pneus e patas de animais no solo), geralmente de pouca profundidade e muita luminosidade, com ou sem alguma vegetação emergente (gramíneas) que os tornam praticamente sombreados, é um mosquito de ocorrência no ano todo com densidade aumentada na estação chuvosaquente (GUIMARÃES e ARLÉ 1984; CONSOLI e LOURENÇO DE OLIVEIRA 1994; REINERT 2000).

Segundo MENEZES (1997), em pesquisas realizadas na área de influência das Hidrelétricas de Canoas I e Canoas II na Bacia do Rio Paranapanema-PR, reconheceu nesta espécie o período de atividade crepuscular vespertina e peri crepuscular. 
FORATTINI $e$ colaboradores, em 1995, estudaram o comportamento de Ochlerotatus scapularis e Oc. serratus em relação às atividades de alimentação e ocorrência em diversos habitats antropicamente modificados no Vale do Ribeira, Estado de São Paulo. Esses autores observaram a tendência de Oc. scapularis para freqüentar o ambiente modificado, sugerindo o desenvolvimento sinantrópico desse mosquito. Enquanto que Oc. serratus, mostrou tendências para áreas de florestas (áreas silvestres).

Oc. scapularis é reconhecido vetor de arboviroses (ARNELL 1976) que acometem o homem e foi suspeito no envolvimento da epidemia do vírus Rocio no Vale do Ribeira-SP (FORATTINI et al. 1995).

Dentre os mosquitos capturados pertencentes ao Gênero Culex foram obtidos os seguintes subgêneros Culex, Melanoconion, Aedinus e Lutzia. A identificação em nível específica se deu pela montagem em lâmina da genitália dos exemplares machos capturados. Os mosquitos deste gênero foram capturados principalmente em armadilhas $\mathrm{CDC}$, que possuiram o horário de funcionamento noturno, estiveram presentes em todas as coletas do periodo.

Seus criadouros são diversificados, variam entre grandes e médias coleções liquidas no solo e bromélias, presença abundante de vegetação flutuantes, submersas e emergentes de gramíneas e algas, de insolação total ou sombreamento parcial. (CONSOLI e LOURENÇO-DE-OLIVEIRA 1994).

O subgênero Culex parece se beneficiar de alterações que o homem introduz no ambiente, em ecótopos naturais e artificiais, indicando desse modo que as espécies do grupo não são tão exigentes quanto aos criadouros, estes podem apresentar uma variação bastante acentuada, desde: água limpa, poluída ou contaminada. Os adultos se abrigam em locais próximos aos seus criadouros ou das fontes de alimentação, caracterizando que o maior relacionamento no ambiente humano sugere uma tendência da espécie à domiciliação, porém não assegurando a obrigatoriedade do subgênero alimentar-se na população humana (GOMES 1990).

Os mosquitos dos subgêneros Melanoconion e Culex atuam essencialmente no crepúsculo noturno, são zoofilicos e exófilos (SALLUM e FORATTINI 1996). 
Os mosquitos destes subgêneros possuem grande importância epidemiológica, por serem considerados potenciais vetores na transmissão de arboviroses, filariose e fator de incômodo (NATAL 1981; FORATTINI 1995).

Segundo DE PAULA (2001) Cx. (Cux.) chidesteri, Cx. (Cux.) coronator são mosquitos que preocupam, devido assumirem o papel de vetores de algumas arboviroses e realizam trânsito entre o ambiente de mata e domiciliar.

Foram capturados 5 exemplares fêmeas de Aedes (Stegomyia) albopictus em armadilha de Shannon em ambos os sítios de coleta, durante os meses de fevereiro e abril. Segundo CONSOLI e LOURENÇO DE OLIVEIRA (1994), este mosquito no Brasil poderá desenvolver o papel de vetor no ciclo silvestre e urbano de febre amarela e de outras arboviroses, por freqüentar os ambientes silvestres, rurais e urbanos.

Os Mosquitos da Tribo Sabethini se mostraram possuir hábitos diurnos, onde todos os exemplares foram capturados no primeiro horário das $17 \mathrm{~h}$ às $18 \mathrm{~h}$.

A ausência de coleta de imaturos das Tribos Sabethini e Mansoniini neste estudo foi ocasionada pela não utilização das técnicas adequadas, já é sabido que imaturos da Tribo Sabethini se desenvolvem em ocos de árvores, axilas de troncos e plantas como bromélias, frestas em rochas e entre outros criadouros. Já os imaturos de Mansoniini se desenvolvem fixando o sifão modificado no aerênquima de plantas aquáticas.

A baixa densidade e diversidade larvária neste inventário podem estar relacionadas com as semelhantes características dos criadouros (fraca correnteza e riqueza de matéria orgânica), a grande proximidade entre os dois pontos de coleta $(500 \mathrm{~m})$ e a oscilação do nível da margem da lagoa, pode ter dificultado o desenvolvimento larvário nos pontos de captura.

Onde estes pontos apresentavam grande quantidade vegetação aquática do gênero Pistia sp. e desprovidos de vegetação terrestre, eram expostos à intensa insolação. 


\section{CONCLUSÕES}

1) No período compreendido entre os meses de Dezembro 2002 a Março 2003, o presente estudo constatou um aumento populacional significativo, onde foram capturados $52,17 \%$ do total dos mosquitos (estação quente e chuvosa). Isto sugere que os culicídeos se beneficiaram destas condições climáticas.

2) Nossas capturas evidenciaram que a distribuição e atividade dos mosquitos sofreram alterações durante as horas do dia e ao longo do ano. Onde obtivemos um índice de Similaridade de $\mathbf{7 7 \%}$ entre os dois sítios de coleta. Tal similaridade pode ter sido causada por variaçð̃es, tanto no microclima, quanto no macroclima. Variações da temperatura, umidade relativa do ar, velocidade e direção dos ventos também podem ter influenciado na atividade dos mosquitos.Os sítios de captura pertencem a mesma região distando apenas $10 \mathrm{~km}$ entre si.

3) A implementação de uma grande coleção hídrica, poderá facilitar o desenvolvimento de populaç⿸尸es potencialmente vetoras, como o caso do $A$. albitarsis l.s., Cq. venezuelensis, Cq. chrysonotum e Oc. scapularis, que já estão presentes na região. Isto ocorreria devido tais condị̧̄̃es ambientais constituirem criadouros ideais para o desenvolvimento destas espécies.

4) Populações de mosquitos desta região que se desenvolvem em criadouros permanentes serão favorecidas, por outro lado grupos como An. (Kerteszia) ou Tribo Sabethini, desenvolvem em criadouros temporários serão drasticamente comprometidas. Isto ocorrerá graças à substituição de ambiente de mata por um ambiente lêntico.

5) A espécie dominante neste estudo foi Ma.titillans com $18,97 \%$ do total de mosquitos capturados. Esta grande ocorrência pode ser explicada devido às condiçð̃es ambientais da área de estudo favorecerem seu desenvolvimento $e$ proximidade do sítio de captura com seu criadouro. 
6) O índice de abundância foi utilizado para exprimir em forma de "ranking" a quantidade numérica e a distribuição temporal das espécies, onde as espécies mais abundantes são pertencentes dos Gêneros Mansonia, Coquillettidea, Adeomyia e Anopheles. Que se desenvolvem em grandes criadouros de áreas impactadas.

7) Este estudo mostrou que as espécies consideradas constantes, acessórias e acidentais, estão distribuídas equitativamente $(27 \%, 35 \%, 38 \%)$, isto sugere que esta área se trata de um ambiente alterado. Onde o índice de constância de uma área preservada apresenta baixa porcentagem de espécies constantes, e alta porcentagem de espécies acidentais. 


\section{RECOMENDAÇÕES}

Do ponto de vista da Saúde Pública a construção de reservatórios e barragens pode propiciar grande proliferação de vetores, intensificando a transmissão de algumas doenças, bem como a introdução de outras. Essa ocorrência inesperada comprova que os problemas potenciais para saúde nas áreas de instalação de barragens e formação de lagos, especialmente as localizadas em regiões tropicais, não são de todo conhecidos. Assim, pesquisas necessitam ser desenvolvidas e, com base nelas, medidas de prevenção e controle. Cada experiência será útil para aperfeiçoar o planejamento epidemiológico de novos empreendimentos.

As doenças transmitidas por vetores têm aumentado atualmente nas diversas regiōes do mundo, sendo as áreas tropicais as mais afetadas. A urbanização, o aumento populacional, empreendimentos de manejo da água, alterações ecológicas, aumento da densidade e expansão geográfica dos vetores, despontam entre as causas desse panorama (TAIPE-LAGOS 2000).

O estudo de espécies vetoras de arboviroses de uma regiáo onde estejam ocorrendo profundas modificações ambientais, é de grande valor do ponto de vista epidemiológico, considerando-se estes estudos como ferramentas essenciais às campanhas de controle.

Dados sobre o comportamento das espécies vetoras constituem parâmetro fundamental, pois as características comportamentais poderão nortear sensivelmente as medidas a serem adotadas para evitar o contato homem-vetor.

Em todas as áreas de influência de lagos artificiais formados, faz-se necessário estudo da composição, abundância, frequêencia e identificação de criadouros de mosquitos Culicidae, bem como outros artrópodos e moluscos de importância médica para que se possam direcionar as medidas de controle e intensificação das ações de vigilância epidemiógica.

Os estudos de levantamento da fauna culicideana nas áreas de influência de empreendimentos hídricos, permitem inferir que há um acréscimo de indivíduos desta população. Isso se dá pela perda de velocidade das águas dos rios (substituição de ambiente lótico por ambiente lêntico), aumentando drasticamente a quantidade de criadouros de mosquitos. Estas mudanças comprometem a qualidade de vida dos 
moradores que vivem nas proximidades dessas áreas, aumentando o incômodo e o risco de transmissão de malária e arboviroses.

Faz-se necessário o estabelecimento de vigilância epidemiológica permanente, bem como a execução de programas de controle de vetores nessas áreas (CONSOLIN et al. 1991). 


\section{REFERÊNCIAS BIBLIOGRÁFICAS}

Arnell JH. Mosquito studies (Diptera: Culicidae) XXXIII. A revision of the Scapularis group of Aedes (Ochlerotatus). Contrib Am Entomol Inst 1976; 13:1144.

Barata JMS, Natal D, Lagos CBT, Urbinatti PR, Rocha RM. Fauna de mosquitos (Diptera: Culicidae) da Bacia do Rio Purus (Acre, Brasil). Identificação de formas imaturas em área de projeto de colonização. Rev Bras Entomol 1993; 37(2): 365-68.

Barbosa, OC, et al., Nota sobre culicídeos adultos na região sul do Brasil. Rev Saúde Pública 1993; 27: 214-6.

Baxter RM. Environmental effects of dams and impoundments. Ann Rev Ecol Syst $1977 ; 8: 255-83$.

Carvalho CM, Conservação da bacia de contribuição e áreas de influência do reservatório da Barragem de Biritiba-Mirim, Sx̃o Paulo. Projeto de Pesquisa apresentado a FEPAF Fundação de Estudos e Pesquisas Agrícolas e Flora, como parte do "Programa de resgate e manejo de fauna silvestre no desmatamento e enchimento dos reservatórios e de conservação do meio ambiente nas Barragens de BiritibaMirim e Paraitinga". 2003.

CasaNova C. Ecologia populacional das fases imaturas de Ae. scapularis rondoni 1848 (Diptera: Culicidae). Campinas; 1994. [Dissertação de Mestrado - Instituto de Biologia da UNICAMP].

CCN, Planejamento e Engenharia S/C Ltda - Relatório de Impacto Ambiental do Sistema Produtor Alto Tietê. 1997; volume único.

Consoli RAGB, Oliveira RL. Principais mosquitos de importância sanitária no Brasil. Rio de Janeiro: FIOCRUZ; 1994.

Consolin J, Luz E, Pellegrini NJM, Torres PB. O Anopheles (Nyssorhynchus) 
darlingi Root, 1926 e a Malária no lago de Itaipu, Estado do Paraná, Brasil: Uma revisão de Dados (Diptera, Culicidae). 1991 Arq Biol Tecnol. 34(2): 263-286.

DAEE. Relatório de impacto ambiental da barragem de Biritiba-Mirim. Internet 2004.

Dajoz R. Ecologia Geral. Trad. De Guimarães FM. Petrópolis: ed. Vozes Ed. USP; 1973.

De Paula MB. Fauna de culicídeos (Diptera: Culicidae) e área sob influência do lago Porto Primavera, município de Presidente Epitácio, São Paulo, Brasil. São Paulo 2001. [Dissertação de Mestrado - Faculdade de Saúde Pública da USP].

Dorvillé LFM. Composição e aspectos da biologia da fauna de mosquitos (Diptera: Culicidae) da restinga de Barra de Maricá RJ. Rev Bras Entomol 1995; 39 (1):20319.

Dorvillé LFM. Mosquitoes as bioindicators of forest degradation in southeastern Brazil, a statistical evaluation of published data in the literature. Stud Neotrop Fauna \& Enviorinm. 31:68-78,1996.

Filho GP. O impacto ambiental das grandes obras do setor Elétrico: $O$ reassentamento da população atingida pela Usina de Itaparica. Rev Adm públ. 22 (3): 95-110, 1988.

Forattini OP. Entomologia Médica. São Paulo: Universidade de São Paulo; 1965 a. v.2.

Forattini OP. Entomologia Médica. São Paulo: Universidade de São Paulo; 1965b v.3.

Forattini OP, Gomes AC, Natal D, Santos JLF. Observações sobre atividade de mosquitos Culicidae em mata primitiva da encosta no Vale do Ribeira, São Paulo, Brasil. Rev Saúde Pública. 1986a; 20(1): 1-20.

Forattini OP, Gomes AC, Natal D, Santos JLF. Observações sobre atividade de 
mosquitos Culicidae em matas primitivas da planície e perfis epidemiológocos de vários ambientes no Vale do Ribeira, São Paulo, Brasil. Rev Saúde Pública. 1986b; 20(3): 178-203.

Forattini OP, Kakitani I, Massad E, Marucci D. Studies on mosquitoes (Diptera, Culicidae) and antropic environment. - Synanthropy and epidemiological role of Aedes scapularis in South-Eastern Brazil. Rev Saúde Pública. 29: 199-207,1995.

Forattini OP. Culicidologia Médica. São Paulo: EDUSP; 1996. v.1

Forattini OP. Culicidologia médica. São Paulo: ArtesMédicas/Edusp; V2, 864p., 2002.

Fundação IBGE. Anuário estatístico do Brasil: 1998. Rio de Janeiro 1999 V58.

Fundação IBGE. Anuário estatístico do Brasil: 1999. Rio de Janeiro 2000 V59.

Gomes AC. Rabello EX, Natal D. Uma nova câmara coletora para armadilha CDCminiatura. Rev Saúde Pública. 1985; 19: 190-1.

Gomes AC. Vigilância Entomológica. Informe Epidemiológico do SUS; 11 (2): 79 $90,2002$.

Gomes AC, Forattini OP. Abrigos de mosquitos Culex (Culex) em zona rural (Diptera: Culicidae). Rev Saúde Pública 1990; 24: 394-97.

Guimarães AE, Arlé M. Mosquitos no Parque Nacional da Serra dos Órgãos, Estado do Rio de Janeiro, Brasil. I. Distribuição estacional. Mem Inst Oswaldo Cruz. 1984; 79:309-23.

Harrington R; Stork NE. Insects in a changing environment. Academic Press. $535 \mathrm{p}, 1995$.

Hunter JM, Rey L, Scott D . Man made lakes, man made diseases. WHO- Wolrd Health Forum. An international jounal of health development. 4: 177-182, 1983. 
Klein TA, Lima JBP, Tang AT. Seasonal distribuition and dial biting patterns of Culicini mosquitos in Costa Marques, Rondônia, Brazil. Men Inst Oswaldo Cruz 1992; 87: 141-8.

Kruijf HAM, Woodall AT, Tang AT. The influence of accumulated rainfall and its patterns on mosquitos (Diptera) populations in Brazil. Bull Entomol Res 1973; 63:327-33.

Lane 1953 a. Neotropical Culicidae. Ed.University of São Paulo. p. 548. V.I

Lane 1953 b. Neotropical Culicidae. Ed.University of São Paulo. 553-1112. VII.

Lechat M.1977. Algunas reflexones sobre la vigilancia Epidemiologica. Boletin informativo del CENETROP. V3, N2 p.63.

Lee JÁ. Effects on inhabitants. World Bank publication. The Jonh Hopkins Press. 1985.

Lopes J. Mosquitos (Diptera: Culicidae) da região do baixo Tỉbagi e suas adaptaçð̃es a ambientes antropogênicos: causas e consequêências. A Bacia Do rio Tibagi. (2002). 327-51.

Lourenço de Oliveira R, Silva TF, Heyden R. Alguns aspectos da ecologia dos mosquitos (Diptera; Culicidae) de uma área de planície (granjas Calábria), em Jacarepaguá; Rio de Janeiro. II. Frequiência mensal e no ciclo lunar. Mem Inst Oswaldo Cruz. 1985a; 80: 123-33.

Lourenço de Oliveira R, Silva TF. Alguns aspectos da ecologia dos mosquitos (Diptera; Culicidae) de uma área de planicie (granjas Calábria), em Jacarepaguá; Rio de Janeiro. III. Preferência horária das fềmeas para o hematofagismo. Mem Inst Oswaldo Cruz. 1985 b; 80(2): 195-201.

Magurram AE. Ecological deversity and its measurement. Cambridge: University Press, 1988. 
Menezes RM. Composição e Atividade de Mosquitos (Diptera; Culiciadae) da Área de influência indireta das Hidrelétricas de Canoas I e II. Bacia do Rio Paranapanema PR, 1993 à 1995. São Paulo; 1997. [Dissertação de Mestrado Departamento de Epidemiologia da Faculdade de Saúde Pública da USP].

Ministério da Saúde. Controle seletivo de vetores da Malária. Guia para nível municipal. Fundação Nacional de Saúde $1^{\circ}$ Ed. Brasilia 1999. P.58.

Ministério do meio Ambiente. Agenda 21 Brasileira. Bases para discussão. Brasilia: MMA 2000.

Mouchet J, Manguin S, Sircoulon J, Laventure S, Faye O, Onapa AW, et al. Evolution of malaria in Africa for the past $\mathbf{4 0}$ years: Impact of climatc and human factors. Journal of the American Mosquito Control Association 1998. 14(2): 121130.

Muller AC. Hidrelétricas, meio ambiente e desenvolvimento. São Paulo: Makron Books do Brasil: 412p. 1995.

Natal D. Importância epidemiológica de Culex do subgênero Melanoconion (Diptera: Culicidae). São Paulo; 1981.[Dissertação de Mestrado - Faculdade de Saúde Pública da USP].

Natal D, Barata EAMF, Urbinati PR, Barata JMS. Contribuição ao conhecimento da fauna de imaturos de mosquitos (Diptera, Culicidae) em área de implantação de Hidrelétrica na bacia de Rio Paraná, Brasil. Revta bras Ent. 1995; 39(4): 897-899.

Natal D. Impactos ambientais e adaptação de culicídeos e implicações epidemiológicas. Apostila da disciplina optativa de pós-graduação oferecida pelo departamento de Epidemiologia FSP/USP. 228p, 1995.

Rachou RG. Anofelinos do Brasil. Comportamento das espécies vetoras da malária. Rev. Bras. Malariol. D. Tropicais. 1958 10(2): 145-81.

Reeves WC.1965. Ecology of mosquitoes in relation to arboviruses. Annu Rev 
Entomol. 10: 25-46.

Reinert JF. New Classification for the composite Genus Aedes (Diptera: Culicidae; Aedini) Elevation of subgenus Ochlerotatus to Generic rank, Reclassification of the other subgenera, and notes on certain subgenera and species. Journal of the American mosquito Control Association. 16 (3): 175-88. 2000.

Roberts DR, Hsi BP. An Index of Species Abundance for use with mosquito Surveillance Data. Environ Entomol 1979; 8 (6): 1007-13.

Rosa LP, Sigaud L e La Rovere EL. As restrições Ambientais na energia elétrica In: Estado, Energia Elétrica e meio Ambiente: 0 caso das Grandes Barragens. Coordenação dos programas de Pós Graduação em Engenharia da Universidade Federal do Rio de Janeiro. 184p. 1995.

Rouquayrol MZ; Almeida-Filho N. Epidemiologia \& Saúde. MEDSI Editora Médica e Científica. Rio de Janeiro, 5ª Ed 600p., 1999.

Rouquayrol MZ; Almeida-Filho N. Epidemiologia \& Saúde. MEDSI Editora Médica e Científica. Rio de Janeiro, 6ª Ed 728p., 2003.

Sallum MAM, Forattini OP. Revision of the Spissipes Section of Culex (Melanoconion) (Diptera: Culicidae). J Am Mosq Control Assoc 1996; 12: 517-97.

Sawyer DR. Frontier malaria in the Amazon Region of Brazil. Types of malaria situations and some implications for control. Simpósio sobre Malária. II Reunião Nacional de Pesquisadores sobre malária. 5 à 9 de junho Centro de Convenções Rebouças, São Paulo Brasil, Resumos/Temas livres.

Service MW. Mosquito Ecology. Sampling adults by baited traps. London, Ed. Applied Science 221-35,1993.

Shannon R. Methods for collecting and feeding mosquitoes in jungle yellow fever studies. Am J Trop Med Hyg. 1939; 19: 131-40. 
Superintedência de Controle de Endemias. (SUCEN). Malária no Estado de São Paulo. Internet, 2004. www.sucen saude.sp.gov.br

Tadei WP, et al. Biologia dos anofelinos amazônicos. VIII conhecimentos sobre a distribuição de espécies de Anopheles na região de Tucuruí-Marabá (Pará). Acta Amazônica. 1983; 13: 103-140.

Tadei WP. O gênero Mansonia (Diptera, Culicidae) e a proliferação de mosquitos na Usina Hidrelétrica de Tucuruí. In: Magalhães SB, Britto RC, Castro ER. Energia na Amazônia. 463p. V1. MPEG/UFPA/UNAMAZ, 1996.

Taipe-Lagos CB. Ecologia de culicídeos em área protegida inserida no ecossistema urbano, 1996-1998, Guarulhos. São Paulo São Paulo 2000. [Tese de doutorado da Faculdade de Saúde Pública USP].

Teodoro U, Guilherme ALF, Lozovei AL, Filho VS, Fukushigue Y, Spinosa RP et al. Culicídeos do lago Itaipu, no Rio Paraná, Sul do Brasil. Rev Saúde Pública, 1995; 29 (1): 6-14.

Van Thiel PH. Malaria problems arising from the construction of a reservoir in the interior of Surinam 1962 Trop geogr Med. 14: 259-78.

Xavier MMSP, Rebêlo JMM. Espécies de Anopheles (Culicidae; Anophelinae) em área endêmica de malária, Maranhão, Brasil. Rev Saúde Pública 1999; 33: 535-41. 


\section{ANEXOS}

A-I Fatores de risco para a Malária segundo o Ministério da Saúde (M.S. 1999):

1-Risco Epidemiológico

Presença de vetores;

Densidade do vetor (larvas e adultos);

Horário da picada;

Comportamento da picada (endofagia, exofagia, endofilia, exofilia, antropofilia);

Suscetibilidade aos inseticidas;

Localização e caracterização de criadouros (mapas);

Capacidade e competência vetorial;

Reservatórios:

Longevidade dos vetores;

\section{2- Ecológicos}

Altura sobre o nível do mar;

Temperatura média anual;

Umidade relativa;

Período de chuvas e níveis de precipitação;

Topografia;

Hidrografia;

Vegetação;

3- Saneamento Básico Ambiental

Tipo de casas;

Eliminação de criadouros;

Drenagem;

Ordenamento dos terrenos

Intervenção dos meios aquáticos;

Flutuação dos níveis da represa; 
Aumento dos fluxos em condições de verão;

Controle da vegetação em meios aquáticos;

4- Sociais

Costumes;

Vestuário;

Medidas de proteção (mosquiteiros, repelentes);

Horário de trabalho:

Migrações (pólos de desenvolvimento, minerações , etc)

Novos assentamentos (colonização);

Ampliação da fronteira agrícola;

Tipo de cultivo e datas de colheita (arrozal);

Educação;

Ocupação principal;

Aceitação de medidas de controle;

População urbana e rural; 
A-II Etapas da Vigilância Epidemiológica, segundo (GOMES 2002)

1- Questão operacional

Definição do vetor;

Definição dos índices de densidade do vetor;

Impacto potencial das medidas de intervenção sobre o vetor;

Custo e factibilidade da intervenção versus eficácia;

Existência de medidas eficazes de profilaxia e controle; $\mathrm{e}$

Identificação de área do vetor sujeita ao risco de transmissão humana.

2- Definição dos objetivos

Conhecer a história natural da doença;

Descrever os ciclos vitais naturais dos vetores;

Identificar as fontes de alimentação sangüínea do vetor;

Identificar mecanismos de envolvimento dos vetores com suas doenças;

Acompanhar a tendência da interação homem-vetor; $\mathrm{e}$

Identificar as ações profiláticas mais adequadas.

3- Identificação dos componentes do Sistema

Periodicidade das coletas do vetor,

Busca de fontes secundárias de informaçōes a serem utilizadas;

Frequiência de análise dos dados. 
A-III Pesquisas de vigilância entomológica e algumas medidas executadas por programas e controle de vetores (MÜLLER 1995; CONSOLIN et al. 1991) :

a) - Conhecimento da fauna culicideana do local de estudo (biologia, ecologia e etologia).

b) - Identificação, mapeamento e numeração de todas habitaçð̃es contidas na área do projeto.

c) - Asperção periódica de inseticidas residuais nas paredes das habitações.

d) - Utilização de drogas anti-malária na população infectada.

e) - Realização de pesquisas para conhecer possíveis predadores naturais dos vetores.

f) -Realização do combate do mosquito em seus criadouros.

g) - Desenvolvimento de sistemas de reservatórios e irrigação com cotas oscilatórias do nivel d'água.

h) - Realização de obras de engenharia (drenagem, desvio de cursos d'água e etc.).

i) - Remoção sempre que possível de macrófitas aquáticas.

j) - Implementação de Pequenas centrais hidrelétricas (PCH)

Dentre tais medidas, sugere-se a telagem das casas e o uso de mosquiteiros, como proteção individual, apresentam efeitos imediatos na referida redução e que, quando somadas às técnicas de manejo ambiental, no sentido das espécies de anofelinos deslocarem seus sítios de procriação, seriam atingidos todos os niveis do ciclo biológico de transmissão na região estudada.

Quanto às áreas rurais, sugerem-se que a localização das casas se dê nos pontos mais altos e distanciados dos criadouros, diminuindo a probabilidade de contato homem-vetor, e que a exploração agrícola e pecuária se disponha diametralmente, em círculos concêntricos a partir das casas, gerando áreas de proteção para as mesmas. 
A-IV Segundo (LEE 1985) algumas questões sanitárias devem ser consideradas na implantação de aproveitamentos hídricos, tais como:

a) - Quais planos serão elaborados para controlar/eliminar os vetores de doenças humanas e seus vetores?

b) - Haverá planos de controlar/eliminar as plantas aquáticas?

c) - Os reservatórios serão protegidos de contaminação por pesticidas e fertilizantes?

d) - O acesso ao reservatório será restringido? Como?

e) - Haverá planos de supervisão médica para todos trabalhadores da represa?

f) - Quais planos serão elaborados para prevenir a infecção de trabalhadores ou residentes locais da introdução de uma doença de outra parte do país?

A-V Outras formas de degradação ambiental decorrentes da formação do reservatório, passiveis de ocorrência:

Mudanças climáticas

Formação de nevoeiros.

Alteração nas taxas de evaporação e evapotranspiração.

Modificações na circulação atmosférica.

Formação de correntes locais de brisa na área do reservatório.

Alteração de nível do lençol freático.

Mudança no perfil longitudinal dos rios que desembocam no lago artificial.

Aumento da umidade do ar à noite.

Aumento das temperaturas. 
A- VI

Culicideos importantes como vetores biológicos

\begin{tabular}{|c|c|c|}
\hline Género/espécie & doença transmitida & agente etiológico \\
\hline \multirow[t]{5}{*}{ Aedes aegypti } & Dengue & Vírus \\
\hline & Febre amarela & Virus \\
\hline & & Chikungunya \\
\hline & & Ross River \\
\hline & & Zika \\
\hline \multirow[t]{2}{*}{ Aedes albopictus } & Dengue & Virus \\
\hline & Febre amarela & Vinus \\
\hline Aedes leucocolaenus & Febre amarela & Vinus \\
\hline \multirow[t]{4}{*}{ Aedes sp. } & Encefalites & Rocio \\
\hline & Filarioses & Zika \\
\hline & & Wuchereria bancrofti \\
\hline & & Brugia malayi \\
\hline \multirow[t]{5}{*}{ Anopheles spp. } & Malária & Plasmodium vivax \\
\hline & & P. falciparum \\
\hline & & P. malarie \\
\hline & Viroses & Vários Virus \\
\hline & Filarioses & Wuchereria bancrofti \\
\hline \multirow[t]{5}{*}{ Culex spp. } & Várias Viroses & Ross River \\
\hline & Encefalites & St. Louis \\
\hline & & Murray Valley \\
\hline & & West Nile \\
\hline & & Rift Valley \\
\hline Culex quiquefasciatus & Filariose Bancroftiana & Wuchereria bencrofti \\
\hline \multirow{4}{*}{ Haemagogus spp. } & Febre amarela & Vinus \\
\hline & Viroses & IIheus \\
\hline & & Una \\
\hline & & Maguari \\
\hline \multirow[t]{4}{*}{ Mansonia spp. } & Filariose & Brugia malayi \\
\hline & Várias Viroses & Chikungunya \\
\hline & & Zika \\
\hline & & VEE vinus \\
\hline \multirow[t]{4}{*}{ Psorophora spp. } & Várias Viroses & VEE virus \\
\hline & & IIheus \\
\hline & & Una \\
\hline & & Mayaro \\
\hline \multirow[t]{2}{*}{ Sabethes spp. } & Viroses & St. Louis \\
\hline & & IIheus \\
\hline \multirow[t]{2}{*}{ Trichoprsopon } & Viroses & Bussuquara \\
\hline & & |liheus \\
\hline
\end{tabular}


A-VII

Efeitos socio-ambienais, decorrentes em áreas de implementação de projetos hídricos:

Perda do valor da propriedade afetada.

Perda de marcos históricos (sítios arqueológicos).

Perda da safra na época da relocação.

Perda de recursos naturais não explorados.

Pesca prejudicada (alta mortalidade dos peixes).

Inundaçăo de cemitérios.

Separação de territórios por braços do lago.

Danos a florestas e outros ambientes naturais.

Erosão, assoreamento, eutrofização e poluição das águas.

Aumento da população (migração de mão de obra)

Sobrecarga dos serviços públicos locais:

Energia elétrica

Trânsito

Comunicaçăo

Segurança

Criminalidadez

Prostituição

Saneamento básico / Favelas

Proliferação de fauna indesejada (Vetores)

Propagação de doenças 
A- VIII As dez maiores represas em volume armazenado em operação ou construção no Brasil até 1990 :

\begin{tabular}{|l|l|l|l|l|}
\hline Usina (empresa) & Ano/Estado & Volume & Capacidade do & Área $\mathrm{Km}^{2}$ \\
& & $\left(\mathrm{x} 10^{6} \mathrm{~m}^{3}\right)$ & vertedouro $\mathrm{M}^{3} / \mathrm{s}$ & \\
\hline Serra da Mesa (Furnas) & $\mathrm{GO} / 1995$ & 55.200 & 15.000 & 1.784 \\
\hline Tucuruí (Eletronorte) & PA/1983 & 45.500 & 100.000 & 2.430 \\
\hline Sobradinho (Chesf) & BA/1979 & 34.100 & 22.850 & 4.214 \\
\hline Itaipu (Itaipu) & PR/PY/1991 & 29.000 & 61.400 & 1.360 \\
\hline Furnas (Furnas) & MG/1963 & 22.950 & 13.000 & 1.450 \\
\hline Ilha Solteira (Cesp) & SP/1973 & 21.166 & 40.000 & 1.077 \\
\hline Três Marias (Cemig) & MG/1960 & 21.000 & 8.700 & 1.059 \\
\hline Porto Primavera (Cesp) & SP/1995 & 18.500 & 52.000 & 2.250 \\
\hline Balbina (Eletronorte) & AM/1989 & 17.500 & 6.450 & 2.360 \\
\hline Itumbiara (Furnas) & GO/1980 & 17.030 & 16.200 & 798 \\
\hline
\end{tabular}

Fonte; (MÜLLER 1995) 
A-IX

O monitoramento epidemiológico desta área de manancial do Sistema Produtor Alto Tietê é de suma importância, vista que esta área apresentou casos autóctones de Malária na ultima década, segundo a Superintendência de controle Endemias de São Paulo.

Casos autóctones de malária, por ano e local provável de infecção. Região da Serra do Mar, 1990 a 2000.

\begin{tabular}{|l|c|c|c|c|c|c|}
\hline & Biritiba- & Embu & Juquitiba & $\begin{array}{c}\text { Mogi das } \\
\text { Cruzes }\end{array}$ & Salesópolis & Sáo Panlo \\
\hline 1990 & - & 1 & - & - & - & - \\
\hline 1991 & - & - & 1 & - & - & - \\
\hline 1992 & - & - & - & - & - & - \\
\hline 1993 & - & - & 4 & 1 & - & - \\
\hline 1995 & 1 & 3 & - & - & - & - \\
\hline 1996 & - & - & - & - & - & - \\
\hline 1997 & - & 1 & - & - & - & - \\
\hline 1998 & - & - & - & - & 1 & - \\
\hline 1999 & - & - & 2 & - & - & - \\
\hline
\end{tabular}

(SUCEN, 2004) 


\begin{tabular}{|c|c|c|c|c|c|c|c|c|c|c|c|c|c|c|c|c|c|c|c|c|}
\hline monet & $\infty \infty$ & 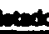 & $\operatorname{cosen} n$ & $\operatorname{mos}$ & and & m & men & (PI.) & cons & Am & Mromein: & nn & topontor & otode & Sthor & ones & 2. aventaph & & & \\
\hline menes & $=0$ & & 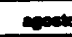 & & 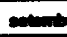 & & $\infty$ & & mens & | & on & $\infty$ & (1) & & m & & $\min$ & Dוm & jant & ו \\
\hline $\operatorname{sen}_{0}$ & $m$ & $F$ & $\mathbf{m}$ & $\boldsymbol{F}$ & $m$ & $\mathbf{F}$ & $m$ & $\mathbf{F}$ & $m$ & $\mathbf{F}$ & $\mathbf{M}$ & $m$ & $\mathbf{M}$ & $\mathbf{F}$ & & $\mathbf{F}$ & $\mathbf{m}$ & $\mathbf{M}$ & $\mathbf{m}$ & \\
\hline 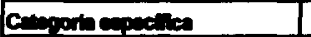 & & & & & & & & & & & & & & & & & & & & \\
\hline Ad. squemipenis & & & & & & 1 & & & & & & & & & & 2 & 1 & & & 4 \\
\hline A0. abopictess & & & & & & & & & & & & & & 1 & & & & & & 1 \\
\hline An abitersis s.!. & & & & & & & & & & & & & & 1 & & & & & & 1 \\
\hline An. cromi & & & & & & 1 & & & & & & & & 1 & & & & & & 2 \\
\hline An coveneses & & 1 & & & & 1 & & 2 & & & & & & 1 & & & & & & 8 \\
\hline An. gaveri & & 17 & & 10 & & 7 & & 2 & & 7 & & & & 1 & & 6) & & 3 & & $\infty$ \\
\hline An intemadius & & 2 & & & & 1 & & & & 1 & & & & & & 1 & & 1 & & 6 \\
\hline An. Ines & & & & 1 & & 2 & & 4 & & & & & & & & d & & & & 7 \\
\hline An. triamulates & & & & & & & & & & & & & & & & 5 & & & & 5 \\
\hline Cq. aldicosede & & & & & & & & & 1] & & & & & & & & & & & 1 \\
\hline Cq. croonotumberione & & & & & & 1 & 1 & 75 & 12 & 51 & 10 & $n$ & & 100 & & 313 & 107 & $\infty$ & & 20 \\
\hline Cq hermerai & & & & & & & & & & & & & & 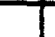 & & 101 & 26 & G) & & 191 \\
\hline Cq jectemeneonia & & & & & & & & & & 1 & & & & & & & 1 & & & 2 \\
\hline C. vencouranis & & & & & & & 1 & 3 & & 0 & 2 & 6 & & $2 \pi$ & & g & & & & 8 \\
\hline 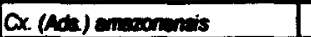 & & & & & & 2 & & & & & & & 1 & 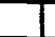 & & a & 1 & & & 13 \\
\hline a. $($ ax. $)$ dobeens & & & & & & & 4 & & 1 & & & & & & 1 & 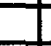 & & & & 6 \\
\hline 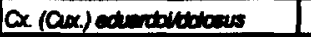 & & & & & & & & & & & 2 & & & & & 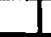 & & & & 2 \\
\hline$a x(a x$,$) o. Coronetor$ & & 1 & & & & & & & & 1 & & 2 & & 3 & & 2 & & & 2 & 11 \\
\hline$\alpha(a x)=p$ & & 1 & & 3 & & 1 & & 5 & & 2 & 1 & 2 & & 2 & & 2 & 7 & 1 & & $2 \pi$ \\
\hline Ox. (utrial) ep. & & & & & & & & & & & & & & & & & & & & 1 \\
\hline 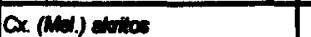 & & & & 1 & & & & & & & & & & & & & & & & 1 \\
\hline Qx. (ned.) ant & & & & & & & & & 23 & & & 1 & 6 & 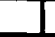 & 30 & & 7 & 2 & & $\omega$ \\
\hline 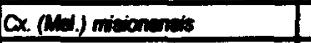 & & & 2 & & & & 5 & & 1 & & & & 2 & 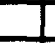 & 2 & & & & & 12 \\
\hline 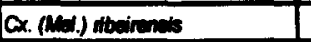 & & & & & & 1 & & & & & & & & 1 & & 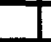 & & & & 2 \\
\hline$a x(n)=\operatorname{mos}$ & & & & 8 & & 3 & & & & & & 2 & & 4 & & 7 & 1 & & & 20 \\
\hline 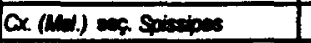 & & & & 1 & & & & & & & & & & 7 & & 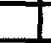 & & & & 1 \\
\hline Ox. (aux.) ningipaters & & & & 2 & & 1 & & & & & & & & 2 & & 4 & & 1 & & 10 \\
\hline Li dutheni & & & & & & & & & & & 3 & 11 & & 12 & & 3 & 2 & & & 31 \\
\hline Mo indeturess & & & & & & & & & & & & & & 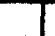 & & 15 & 4 & & & 20 \\
\hline Me wers & & & & 3 & & 40 & & 20 & & 44 & s) & 17 & & 20 & & $\infty$ & 36 & 10 & & $2 \pi$ \\
\hline Me witioni & & & & & 2 & & & & & & & & & - & ? & 1 & 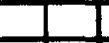 & 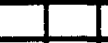 & & 10 \\
\hline Qc. odinter & & & & & & & & & & & & & & 1 & & 1 & 5 & & & 8 \\
\hline Oc. expoperis & & & & 2 & & & & & & 3 & & (1) & & 6 & & 8 & 2 & & & 22 \\
\hline$\alpha$ c sorrcturntilus & & & & & & & & & & 4 & & 1 & & & & 1 & 3 & & & 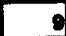 \\
\hline Ph. ep. & & & & & & & & & & & & & & & & & & 1 & & 1 \\
\hline Ph. theodede & & & & & & & & & & & & 1 & & & & & & & & 1 \\
\hline 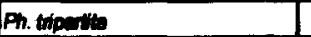 & & & & 1 & & & & & & & & & & & & & & 1 & & 2 \\
\hline Pr. eltionen & & & & & & & & & & 1 & 1 & & & & & & & & & 2 \\
\hline$P$ P. nox & & & & & & & & & & & & 3 & & & & 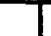 & & & & 3 \\
\hline Ru reveres & & & & 2 & & & & & & & & c) & & e] & & ef & 4 & & & 20 \\
\hline So forctini & & & & & & & & & & & & 1 & & T & & & & & & 1 \\
\hline Sa.intermadives & & & & & & & & & & 1 & & 1 & & 1 & & . & & & & 3 \\
\hline 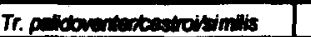 & & & & & & & & & & & & 1 & & 3 & & & 1] & & & 8 \\
\hline Ut. dontion & & & & & & & & 1 & & & & & & 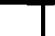 & & & 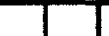 & & & 1 \\
\hline Ur. puctersing & & & & 1 & & 1 & & & & & & & & & & & & & & 2 \\
\hline Wy. minosi & & & & & & & & & & & & & & 1 & & & & & & 1 \\
\hline W. contios & & & & 7 & & 4 & & 1 & & 1 & & 17 & & 10 & & 11 & 6 & & & 6 \\
\hline m. anvis & & & & 1 & & & & & & & 1 & 3 & & 2 & & 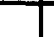 & & & & 7 \\
\hline Wh. odverdit & & & & 7 & & 1 & & 3 & & 6 & 1 & 51 & & 28 & & 9 & d & & & 116 \\
\hline 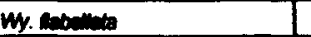 & & & & & & & & & & 2 & 3 & 2 & & 3 & & 5 & 7 & & & 22 \\
\hline iw. incoudente & & & & & & & & 1) & & 6 & 5 & 1) & & 1 & & & & & & 13 \\
\hline WY. pellidiventer & & & & & & & & & & & & 20 & & 11 & & 1 & 3 & & & 3 \\
\hline wy. ap & & & & & & & & & & & 1) & & & 4 & & 2 & & & & 7 \\
\hline iw. splendicte & & & & 1 & & & & & & & 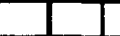 & & & 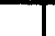 & & & & & & 1 \\
\hline W. thoobeld & & & & & & & & & & & & & & 1 & & & & & & 1 \\
\hline Sutwent & of & 20 & 2 & 51 & 2 & 6 & 11 & 117 & 30 & 140 & 34 & \begin{tabular}{|l|l|}
200 \\
\end{tabular} & & 206 & 418 & ser & \begin{tabular}{|l|l|}
10 & 204 \\
\end{tabular} & $2 \mid 114$ & d & 1203 \\
\hline Totent & & 20 & & $\infty$ & & 61 & & 120 & & 170 & 36 & 20 & & 201 & & $\infty$ & 200 & 118 & & 1800 \\
\hline
\end{tabular}




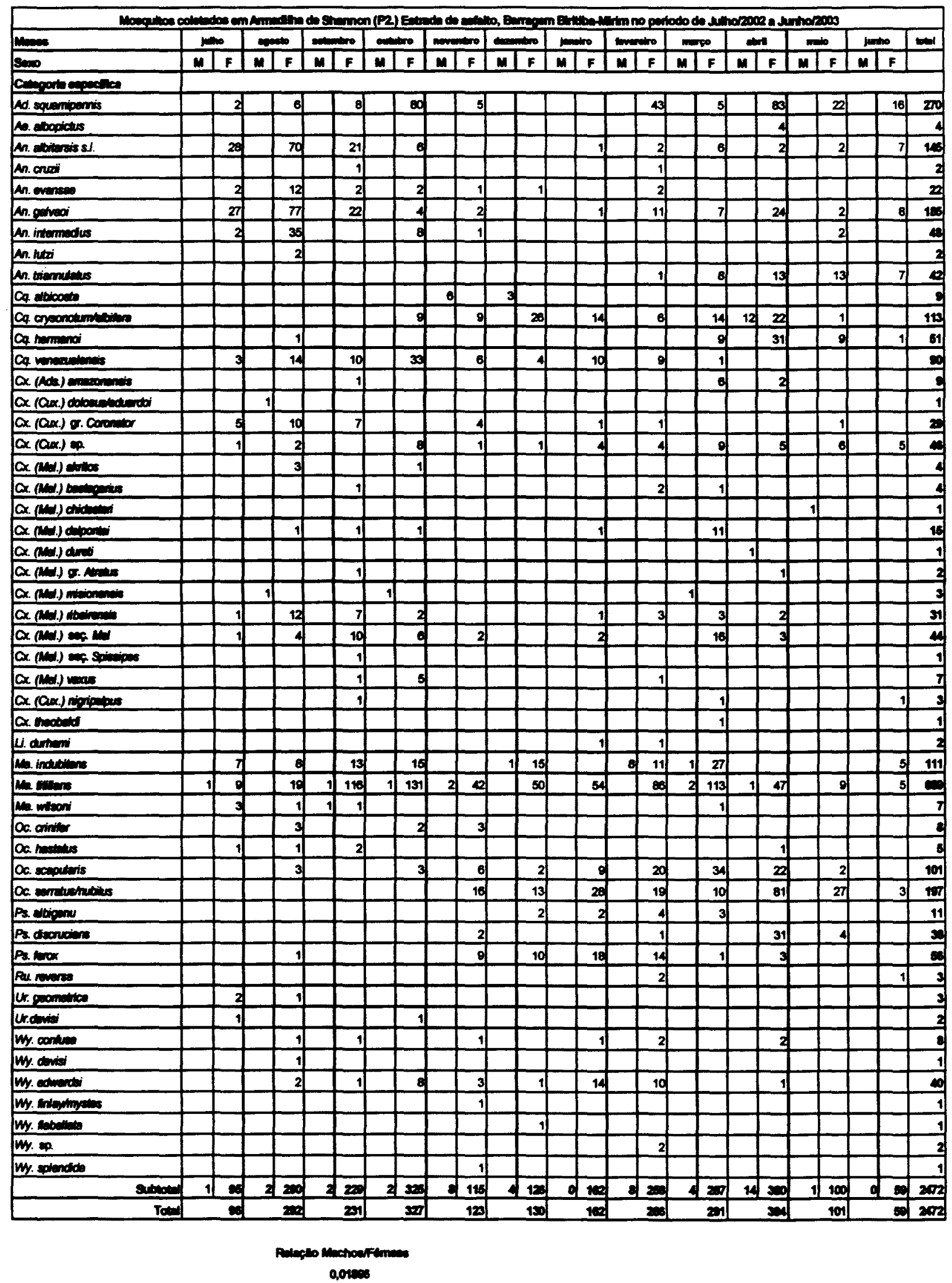




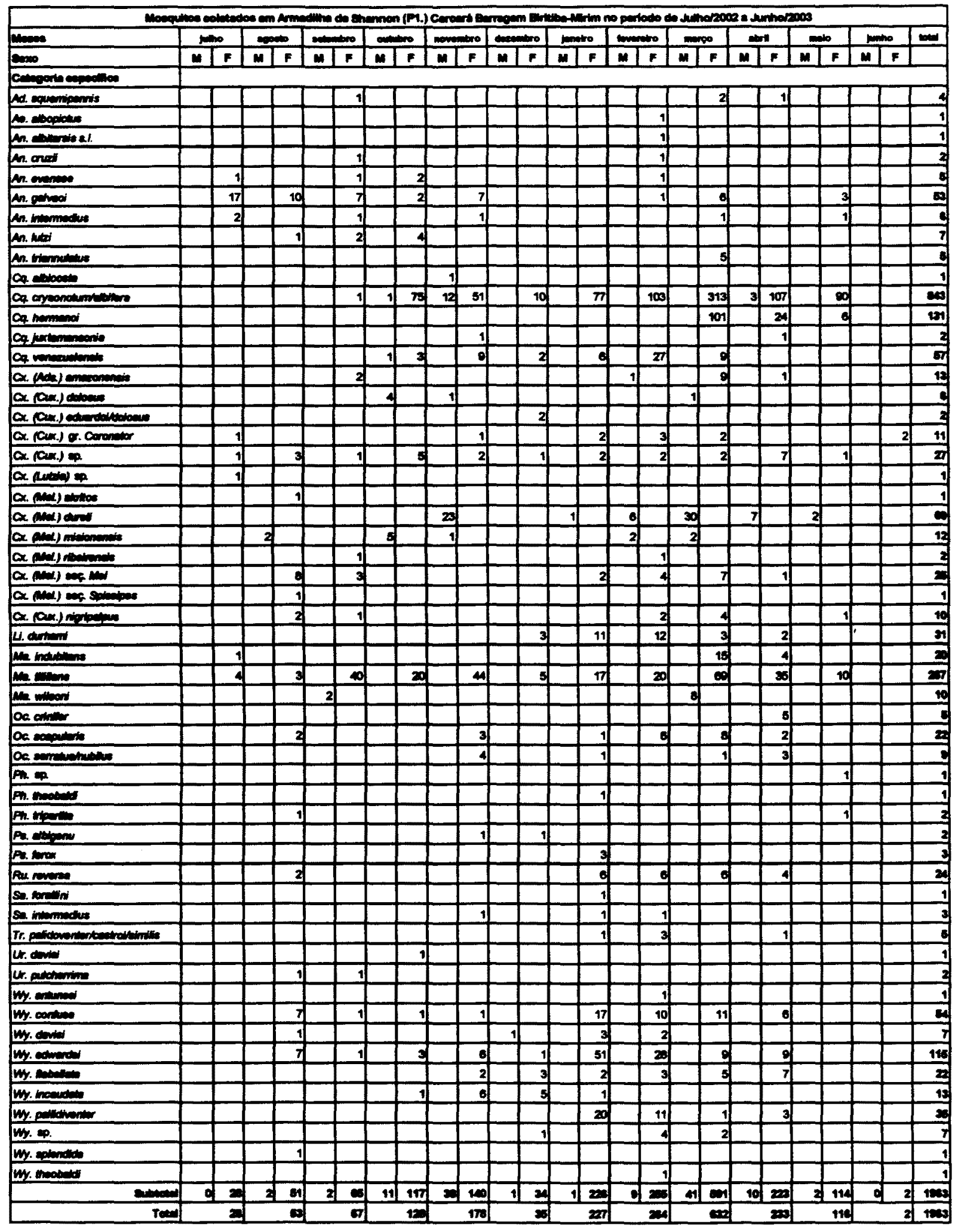




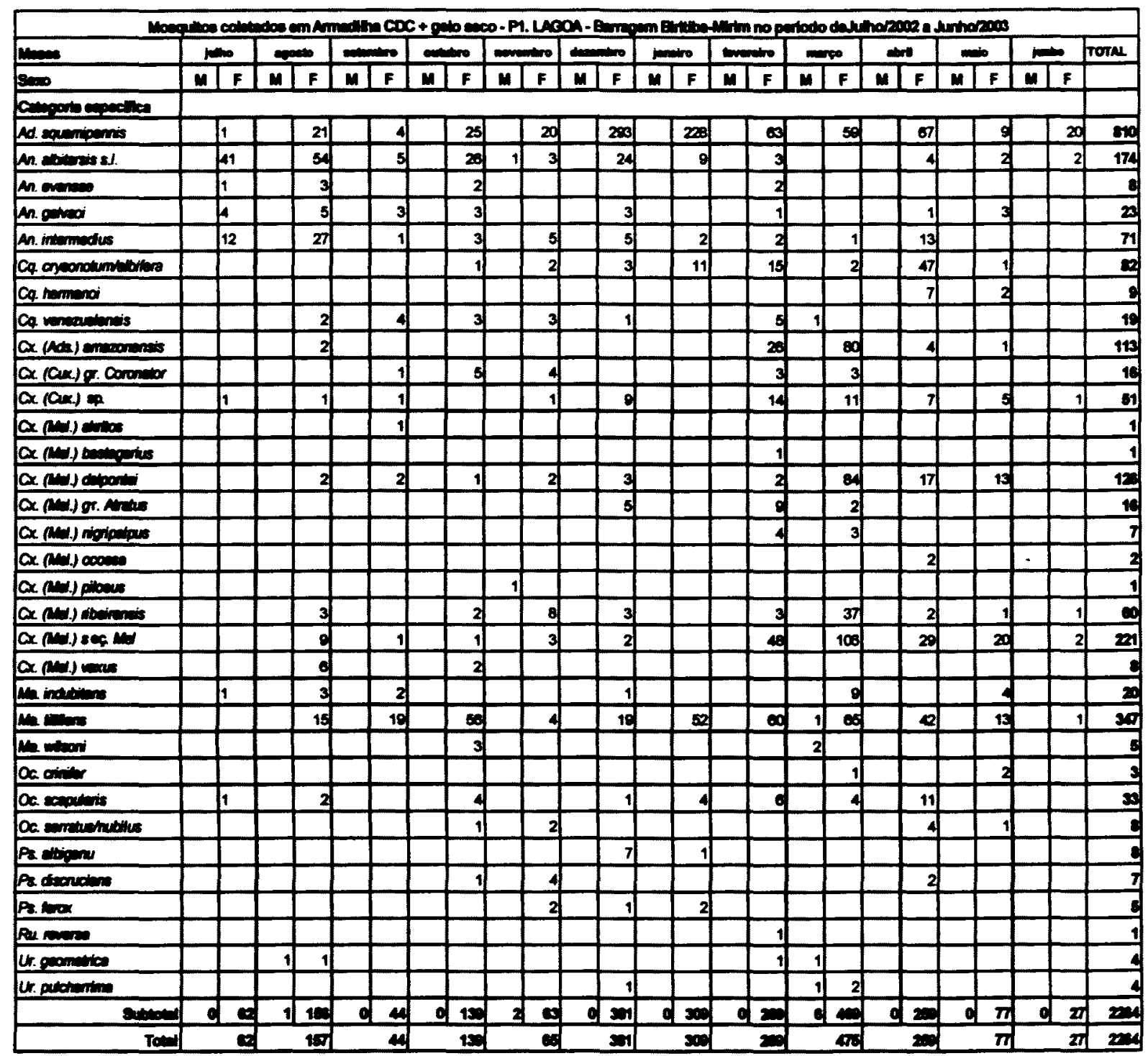

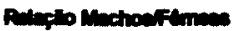

apaces 


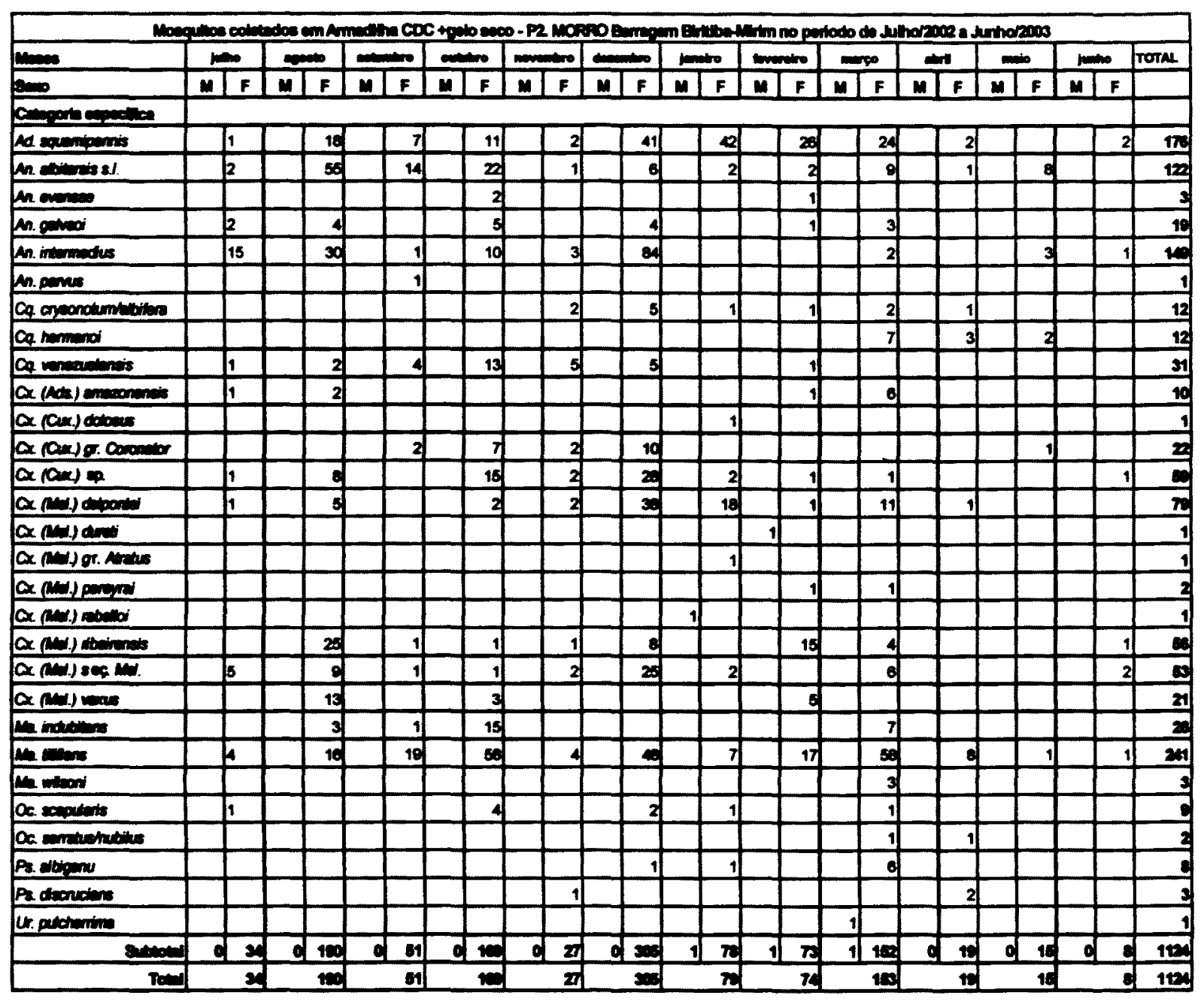

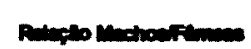




\begin{tabular}{|c|c|c|c|c|c|c|c|c|c|c|c|c|c|}
\hline \multicolumn{14}{|c|}{ 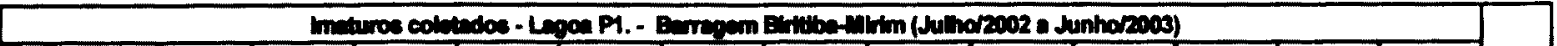 } \\
\hline$=$ & $=$ & $\infty$ & (1) & - & $I$ Im & $=1$ & mo & 然 & $=$ & 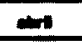 & mo & o & \\
\hline 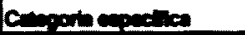 & & & & & & & & & & & & & TOTA \\
\hline Ad squen & 4 & & 1 & 5 & 3) & 24 & 58 & 21 & & 6 & 2 & & $\overline{145}$ \\
\hline An. Ebitasis s.l. & & & 3 & $\overline{8}$ & ( & & & 1 & & 3 & & & 26 \\
\hline C. $(a \alpha$.$) edrerdo$ & & & & $\underline{2}$ & & & & & & & & & 8 \\
\hline$\alpha \cdot(a x) 8 p$. & 1 & & & & & & & & & & & & 1 \\
\hline C. (Ltria) sp. & & & & & & & 1 & & & & & & 1 \\
\hline Ps. albigonu & & & & & & 6 & & & & & & & 6 \\
\hline TOTAL & 6 & 8 & 4 & 17 & 3 & 30 & 5 & $\overline{22}$ & $\overline{0}$ & 9 & $\overline{2}$ & & 187 \\
\hline
\end{tabular}

\begin{tabular}{|c|c|c|c|c|c|c|c|c|c|c|c|c|c|}
\hline \multicolumn{14}{|c|}{ 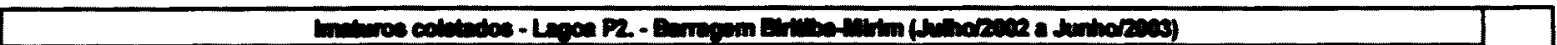 } \\
\hline $\mathbf{m}$ & $=$ & $=$ & $=$ & 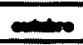 & Im & $=$ & on & 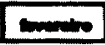 & $=$ & 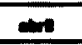 & $=$ & $=$ & \\
\hline 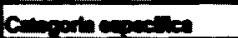 & & & & & & & & & & & & & TOTN \\
\hline Ad squeniperris & & & & 4 & 4 & 8 & 41 & 21 & 4 & 16 & & & 107 \\
\hline An. Ebitesis sl. & & 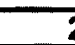 & & $\overline{3}$ & 2 & & 1 & & & $\overline{1}$ & & & 14 \\
\hline An. Gvanses & & & & & & & & & & & & & 1 \\
\hline Ps. ebigenu & & & & & & 6 & & & & & & & 6 \\
\hline Ps. forex & & & & & & 1 & & & & & & & 1 \\
\hline TOTAL & & & 0 & 7 & 6] & 15 & 42 & 21 & 5 & 17 & & & 120 \\
\hline
\end{tabular}




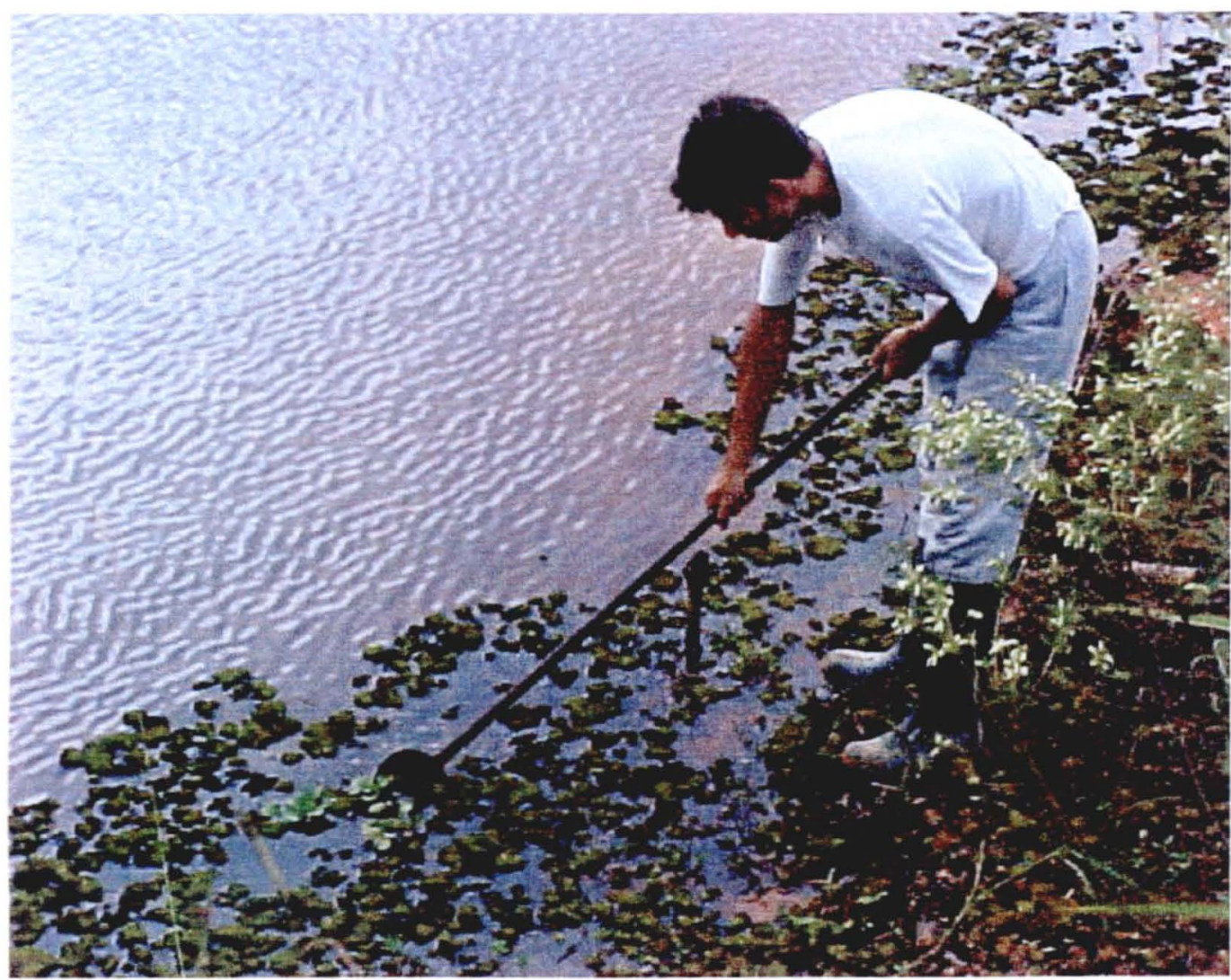

Foto 1: Coleta de imaturos (Lagoa I)

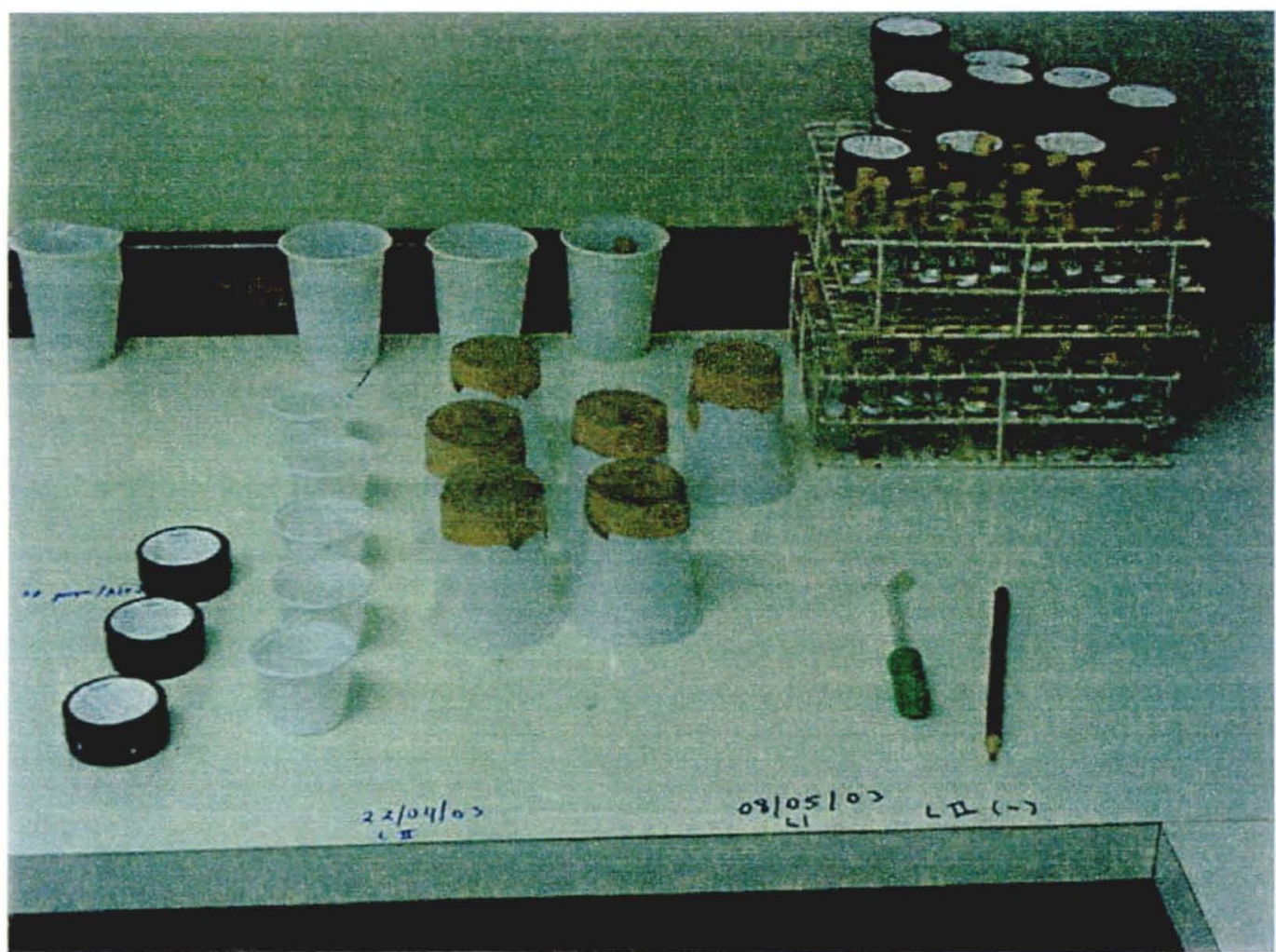

Foto 2: Criação de imaturos em laboratório 


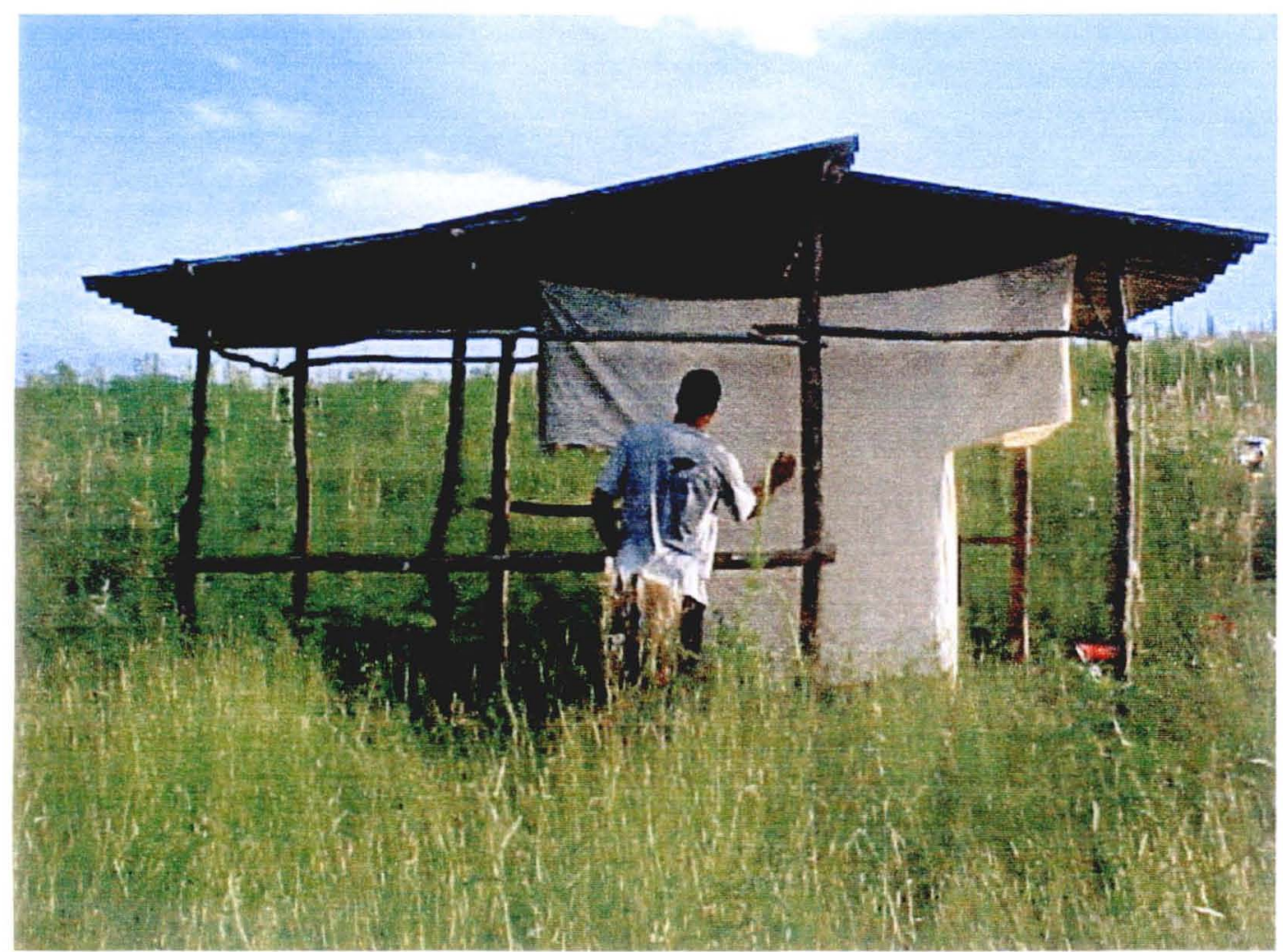

Foto 3: Armadilha de Shannon

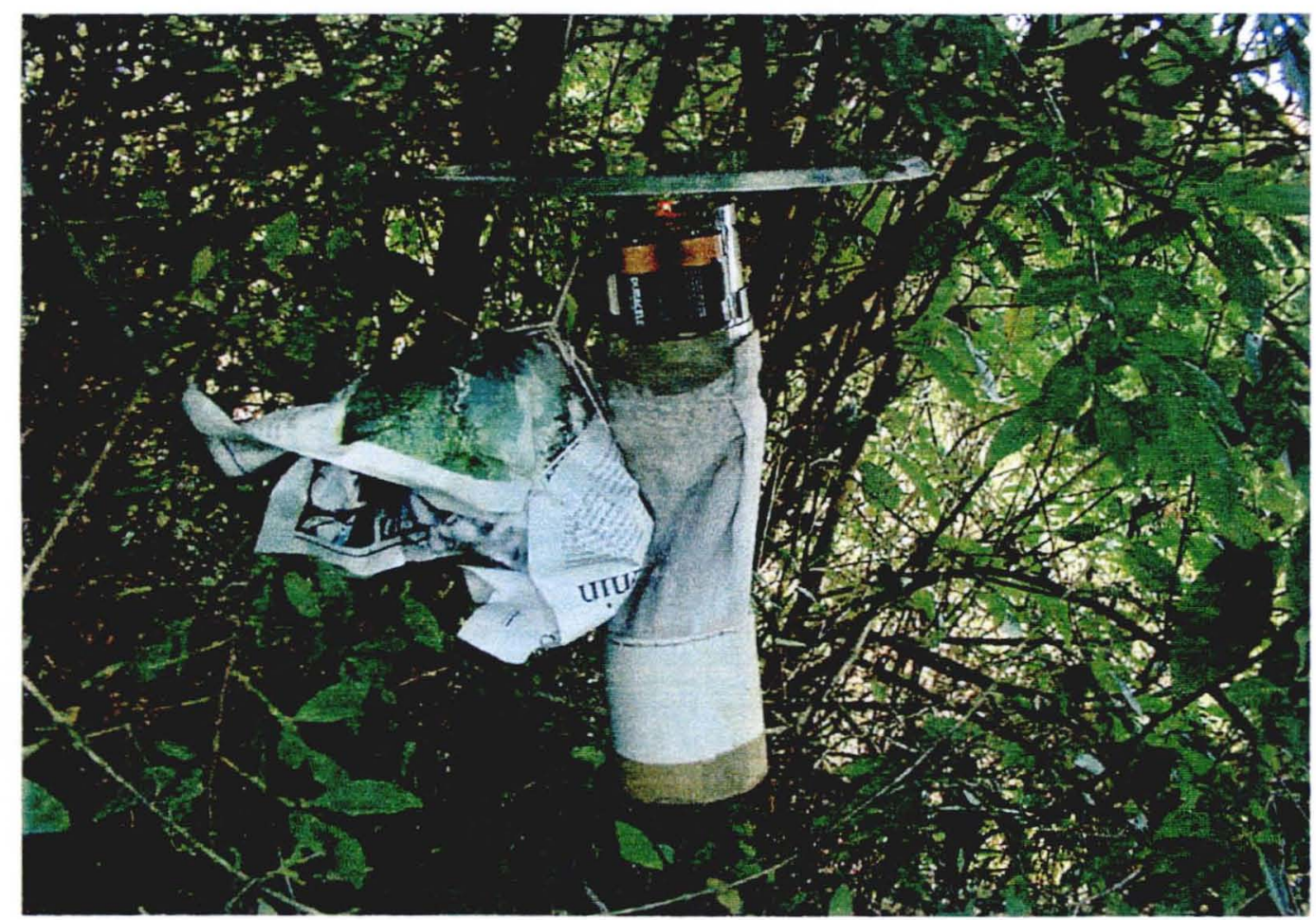

Foto 4: Armadilha CDC (Morro) 


\section{PROJETO MOGI:}

\section{ADULTOS}

LOCALIDADE

TÉCNICA DE CAPTURA

ÁREA

SUB ÁREA

HORÁRIO

DATA

\begin{tabular}{|c|c|c|c|c|c|}
\hline$n^{\circ}$ linha & ESPÉCIE & CÓDIGO & forma & sexo & QUANTIDADE \\
\hline & & & & & \\
\hline & & & & & \\
\hline & & & & & \\
\hline & & & & & \\
\hline & & & & & \\
\hline & & & & & \\
\hline & & & & & \\
\hline & & & & & \\
\hline & & & & & \\
\hline & & & & & \\
\hline & & & & & \\
\hline & & & & & \\
\hline & & & & & \\
\hline & & & & & \\
\hline & & & & & \\
\hline & & & & & \\
\hline & & & & & \\
\hline & & & & & \\
\hline & & & & & \\
\hline & & & & & \\
\hline & & & & & \\
\hline & & & & & \\
\hline & & & & & \\
\hline & & & & & \\
\hline & & & & & \\
\hline
\end{tabular}

Observações: 